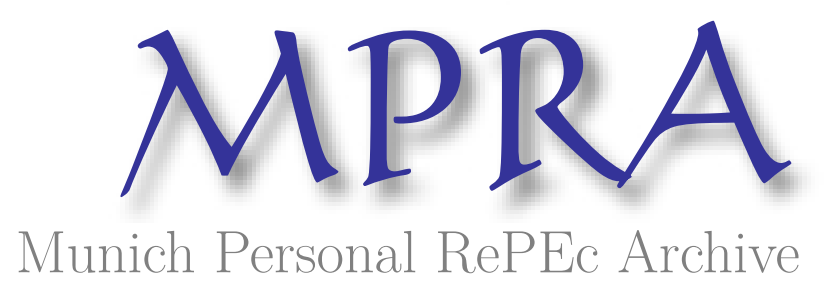

\title{
On the Impact of Financial Inclusion on Financial Stability and Inequality: The Role of Macroprudential Policies
}

Emara, Noha and El Said, Ayah and Pearlman, Joseph

Rutgers University, City University of London

2019

Online at https://mpra.ub.uni-muenchen.de/99258/

MPRA Paper No. 99258, posted 30 Mar 2020 10:25 UTC 


\section{On the Impact of Financial Inclusion on Financial Stability and Inequality: The Role of Macroprudential Policies}

Ayah El Said, Ph.D.

Department of Economics

City University of London

E-mail: ayah.el-said.1@,city.ac.uk

Noha Emara, Ph.D. (Corresponding Author)

Department of Economics

Rutgers University, the State University of New Jersey

311 North 5th Street

Camden, NJ 08102, USA

Tel: 856/225-6765

E-mail: nemara@,camden.rutgers.edu

Joseph Pearlman, Ph.D.

Department of Economics

City University of London

E-mail: avah.el-said.1@,city.ac.uk

JEL Classification Numbers: C23; G21; O43

Keywords: Financial Inclusion; Governance; Economic Growth; MENA; Financial Development

\section{Abstract}


Financial Inclusion - access to financial products by households and firms - is one of the main albeit challenging priorities, both for Advanced Economies (AEs) as well as Emerging Markets (EMs), even more so for the latter. Financial inclusion facilitates consumption smoothing, lowers income inequality, enables risk diversification, and tends to positively affect economic growth. Financial stability is another rising priority among policy makers. This is evident in the re-emergence of macroprudential policies after the global financial crisis, minimizing systemic risk, particularly risks associated with rapid credit growth. However, there are significant policy tradeoffs that could exist between both financial inclusion and financial stability, with mixed evidence on the link between the two objectives. Given the importance of macroprudential policies as a toolbox to achieve financial stability, we examine the impact of macroprudential policies on financial inclusion - a potential cause for financial instability if not carefully implemented. Using panel regressions for 67 countries over the period 2000-2014, our results point to mixed effects of macroprudential policies. The usage (and tightening) of some tools, such as the debt-to-income ratio, appear to reduce financial inclusion whereas others, such as the required reserve ratio (RRR), increase it. Specifically, both institutional quality and financial development appear to increase the effectiveness of macroprudential policies on financial inclusion. Institutional quality helps macroprudential policies boost financial inclusion, with mixed effects as a result of financial development, but the results are more significant when we include either institutional quality or financial development. This leads us to believe that macroprudential policies conditional on better institutional quality and financial development improves financial inclusion. This has important policy implications for financial stability. 


\section{Introduction}

Financial inclusion - access to, and use of, financial products and services by households or firms - is one of the main, albeit challenging priorities in Emerging Markets (EMs), and a key factor for financial development ${ }^{1}$. Regional blocs ${ }^{2}$ and international financial organizations, including the World Bank, the International Monetary Fund, the Asian Development Bank, and the African Development Bank, are among the many entities currently prioritizing access to finance. Financial inclusion units, both within Central Banks, and Finance Ministries, have been on the rise, and bolstering access to finance has become an issue that has been repeatedly addressed in various G-20 statements (see Beck, 2016)). ${ }^{3}$ Over the last decade, the global average of ATMs per 100,000 adults has increased by at least two thirds, ${ }^{4}$ while the global average of holders - especially for depositing purposes - has more than doubled (IMF, 2018), as shown in Figure (1).

\section{Figure (1): Evolution in Financial Inclusion Trends Over the Last Decade}

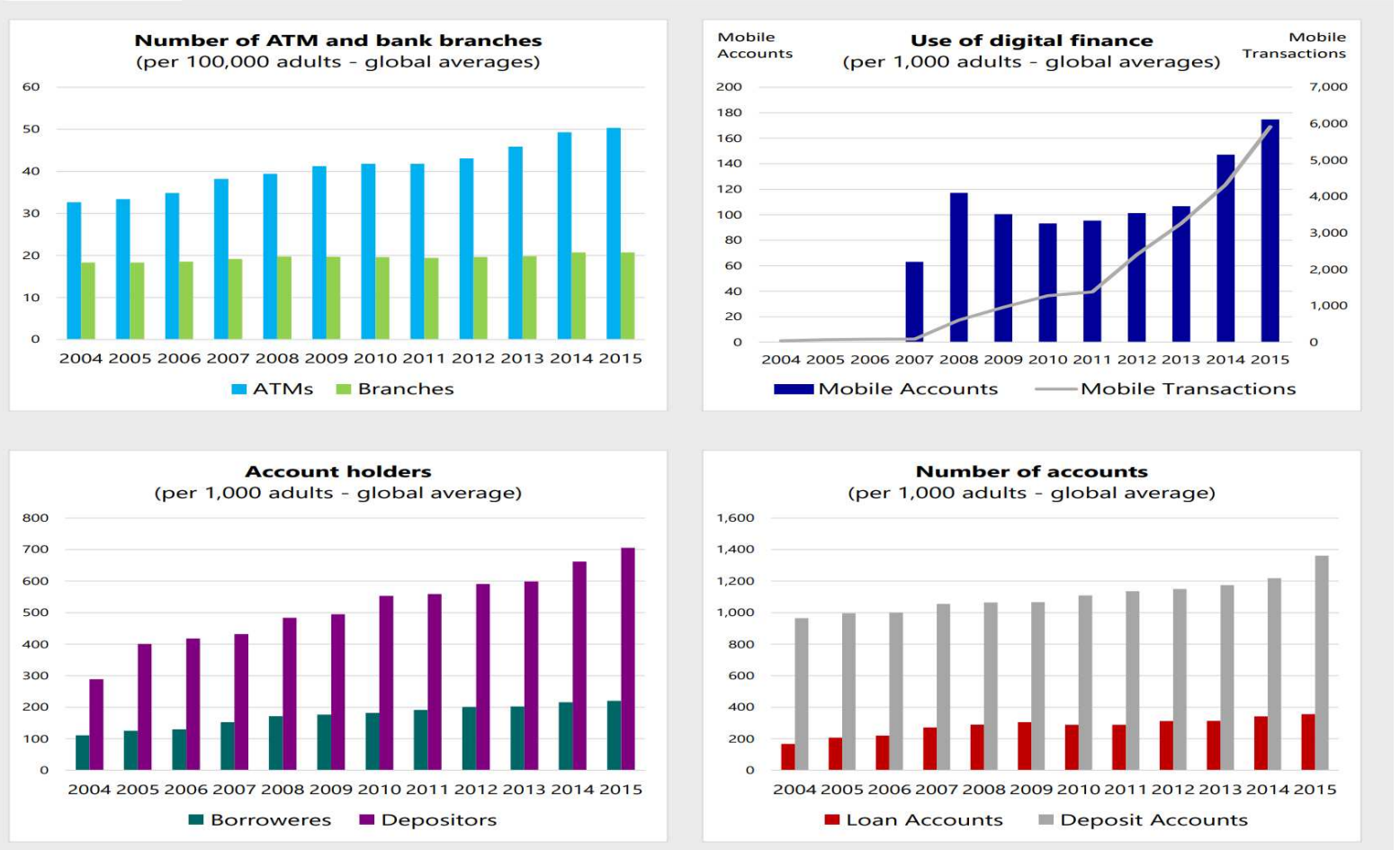

\footnotetext{
${ }^{1}$ The literature on financial inclusion over the last decade established that financial development goes well beyond economic growth (see for example Beck, 2016), Levine, 2005, and Beck, 2009), with financial development contributing to improved income distribution, and reduced poverty (Beck, 2016), even if financial inclusion was lagging

2 G20, APEC, ASEAN, and GCC.

${ }^{3}$ Yet, still over half of the central banks globally have no financial inclusion mandate, but rather objectives related to financial inclusion (Tissot and Gadanecz, 2017).

${ }^{4}$ From 30 in 2004, to almost 50 in 2015.
} 
Financial inclusion is of key importance, particularly to EMs and frontier markets whose levels of financial development, as well as access to finance, are well below those of advanced economies. Financial inclusion can thus help consumption smoothing with significant welfare gains (see, for example, Jappelli and Pagano, 1989; Bacchetta and Gerlach, 1997; Ludvigson, 1999), and help in lowering income inequality by increasing the income of the poorest quintile (Beck et al., 2007), thus boosting savings (Dupas and Robinson, 2013). Moreover, it can act as a lever to reduce the significant rise in extreme global inequality (IMF, 2018), while playing a crucial part in risk diversification and building trust in the financial system, (Cihak et Al., 2016), something that EM and frontier economies lack. Its contribution, therefore, when it comes to growth (IMF, 2016), as well as in terms of alleviating poverty and inequality, cannot be ignored. Ideally, financial inclusion should ensure the sufficient provision of financial services to households, corporates, and governments, in order to improve individual (and overall) welfare (Beck, 2016), without jeopardizing financial stability.

Conversely, financial stability is another priority among global policy makers (see Basel III, and the Financial Stability Board, for example), and macroprudential policies have re-emerged as an important policy tool for achieving financial stability and minimizing risks (systemic, mainly) created by rapid credit growth. ${ }^{5}$ However, policy trade-offs could exist between both financial inclusion and financial stability (see Gould and Melecky, 2017 and Tissot and Gadanecz, 2017). On the one hand, increased usage of macroprudential policies lowers credit growth in the quest to achieve financial stability, ${ }^{6}$ even though one of the less discussed priorities of both financial stability and macroprudential policies is the stable provision of financial intermediation services ${ }^{7}$ to the economy (Bank of England, 2009). On the other, a rapid increase in financial inclusion (via credit expansion) can jeopardize financial stability, as not all borrowers may be creditworthy. The global financial crisis, triggered by the U.S. subprime mortgage crisis, is the epitome of this jeopardy whereby excessive borrowing, and thus more financial inclusion, implied less financial stability. Among EMs, there was the 2010 Andhra Pradesh microfinance crisis (India) as a consequence of the rapid growth of microfinance entities in South India. Both crises provide examples of a deteriorating financial sector, or non-financial sector balance sheets, as a result of increased financial inclusion. There

\footnotetext{
${ }^{5}$ More broadly, any risks that can jeopardize the health of the banking/financial sector.

${ }^{6}$ Refer to Chapter Two for the relevant literature.

${ }^{7}$ Specifically highlighting payment services, credit intermediation and insurance against risk in the quest to circumvent boombust cycles in liquidity and credit supply in a similar manner to the global financial crisis (Galati and Moessner, 2011).
} 
is also a possibility that financial inclusion affects the transmission of monetary policies, adversely affecting financial stability (see Mehrotra and Yetman, 2015). Hence, there could be unintended, or indirect, consequences of an inappropriate implementation of policies and targets (Cihak et al., 2016; Ayyagari et al., 2017).

Given the importance of managing credit cycles, particularly through the use of macroprudential policies, the aim is to examine the link between macroprudential policies and financial inclusion, both in AEs, and EMs. There has been an increase in the literature on the link between financial inclusion and financial stability (see Han and Melecky, 2013, and Morgan and Pontines, 2014, for example). However, to our knowledge, the link between financial inclusion and macroprudential policies is barely examined. ${ }^{8}$ The reason we focus on financial inclusion is twofold: first, the rising literature on both the redistributive and unintended consequences of macroprudential policies ${ }^{9}$ attempts to examine their impact onincome inequality. Second, the IMF (2018) and others, established that financial inclusion does reduce income inequality. ${ }^{10}$ Thus we aim to tackle several of the ongoing issues surrounding macroprudential policies that have not been sufficiently examined in the literature. Specifically, we will address the following questions:

1. How do changes in the various types of macroprudential policies affect financial inclusion?

2. How does the level of financial development and institutional quality - both important factors for financial inclusion - influence the effectiveness of macroprudential policies?

Given the rising literature on the redistributive impact of macroprudential policies and their impact on income inequality, we focus on household financial inclusion ${ }^{11}$ by examining both 
aspects of financial inclusion: access and usage of financial services. Making this distinction is important, as access, in terms of availability of financial services does not imply their usage - borrowing, and depositing - by households. ${ }^{12}$ In this case, financial access, the broadest sense of which is owning an account at a formal financial institution, is necessary for financial inclusion. However, it is insufficient for using formal financial services (Pal and Pal, 2012). We aim to answer these questions by using various macroprudential variables that capture the usage of these tools, and whether these tools have been tightened or loosened, to understand their dynamics.

Section II briefly highlights the recent trends in financial inclusion globally; section III reviews the relevant literature; section IV outlines the data used for our estimation; section V explains the methodology employed; section VI presents our results; and section VII presents our conclusions.

\section{Recent Trends in Financial Inclusion ${ }^{13}$}

$\mathrm{EMs}^{14}$ have been characterized by lower levels of financial development relative to AEs. The fact that most of EMs' financial systems continue to be bank-based meant that financial inclusion is lower among these economies relative to AEs. There is also a preference for using informal financial services - the most basic form of which is borrowing from family - due to the lack of trust in the formal financial system. The high collateral requirements, low share of firms with credit and high borrowing costs, constrain financial inclusion efforts, particularly among frontier markets, even relative to EMs (Dabla-Norris, 2015). ${ }^{15}$

In the last decade, prioritizing financial inclusion has led to newer datasets that attempt to capture access to finance at more disaggregated levels beyond merely account ownership, which still remains an important tool to gauge progress on financial inclusion. As Figure 1 shows, accounts in financial institutions are still the main driver behind financial inclusion, with mobile money accounts on the rise among developing countries. Yet this trend is not uniform (see Figure 4) and the pace of account ownership has been much faster in some countries (Egypt and India) compared to others (Philippines and Mexico), while remaining largely unchanged in EMs between 2014-2017 (World Bank, 2018).

\footnotetext{
${ }^{12} \mathrm{Pal}$ and $\mathrm{Pal}$ (2012) note that usage of financial services may not occur even if there is access due to the lower cost of informal financial services, and the higher price of financial services relative to other good.

${ }^{13}$ Data and Charts for this section are obtained from the World Bank's 2017 Findex Database (World Bank, 2018)

${ }^{14}$ And frontier markets

${ }^{15}$ However, data on macroprudential policies in lower-income and frontier market is not available, so we exclude them from our estimations when splitting the sample within our robustness checks.
} 
Figure 1: Financial institution accounts is the main driver behind growth in account ownership since 2011

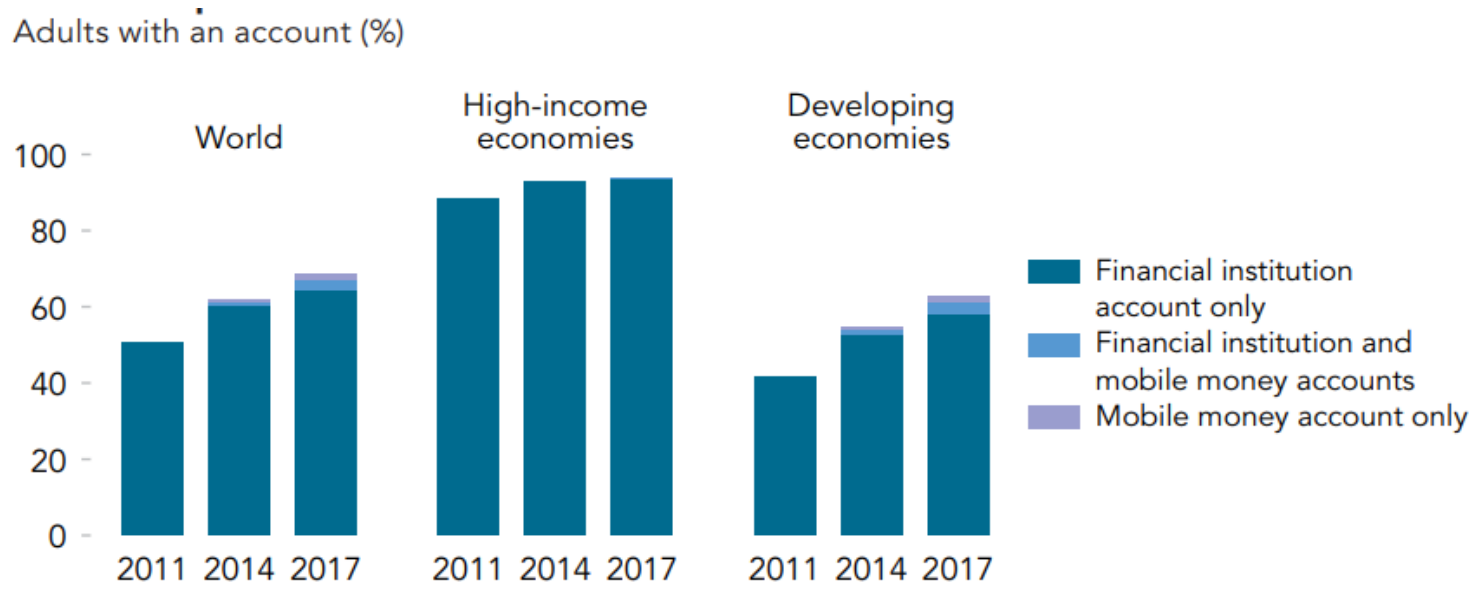

Source: 2017 Global Findex Database

Despite the rise in account ownership, Figure 2 shows that poorer adults are less likely to own an account compared to richer adults, with a global gap of almost $13 \%$. Specifically, $74 \%$ among the richest $60 \%$ globally have a bank account, whereas only $61 \%$ among the poorest $40 \%$ of households do. This gap is even larger, at 15\%, among developing countries. Figure 2 also shows the countries with a gap in account ownership between rich and poor households, both among economies with high account ownership - such as Brazil and China (with a 20\% gap between rich and poor adults), as well as those with low account ownership (such as Egypt and Indonesia, with a gap of also around 20\%). Such gaps do not exist in high-income countries except for some, such as Israel (World Bank, 2018).

Figure 2: Lower likelihood of Poorer Adults to Own an Account, with a Larger Gap of Account Ownership among Developing Countries

Adults with an account (\%), 2017

World

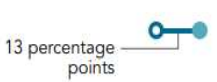

High-income
economies

Developing

economies

0
Adults with an account $(\%), 2017$

Economies with relatively high account ownership

Brazil
China

India

Russian Federation

South Africa

Turkey
Economies with relatively low account ownership

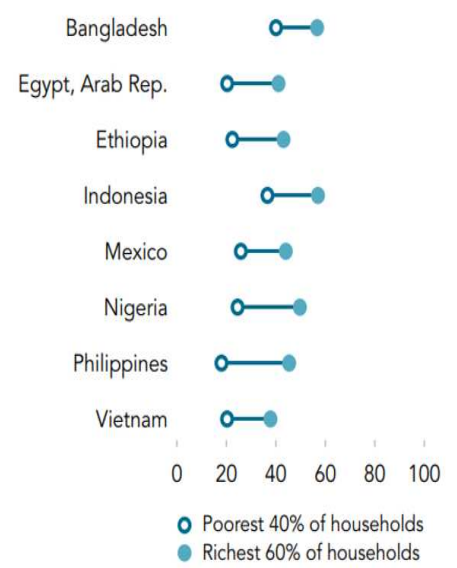


Figure 3 shows that this gap in account ownership has barely changed since 2011 . Richer adults were $17 \%$ more likely to have an account compared to poorer adults since 2011 . However, this gap slightly tapered among developing countries, decreasing from around $20 \%$ to around $14 \%$ in 2014, and stabilizing since then (World Bank, 2018).

Figure 3: Minor Changes in the Gaps in Account Ownership Between the Richer and the Poorer Over Time: Adults with an Account (\%)
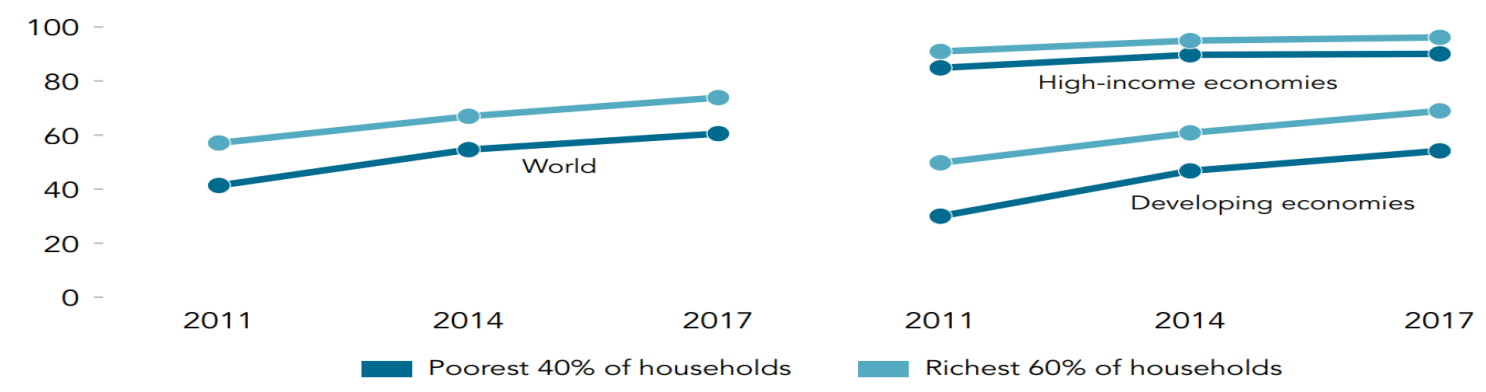

Source: 2017 Global Findex Database

Figure 4 highlights the varying progress in financial inclusion among EMs, with the share of adults owning a bank account almost doubling over the period 2011-2017 (see, for example, the case of India and Egypt). Other countries, however, saw smaller change in account ownership, as in the case of Pakistan and the Philippines (World Bank, 2018).

\section{Figure 4: Varying Progress Towards Account Ownership Among EMs}

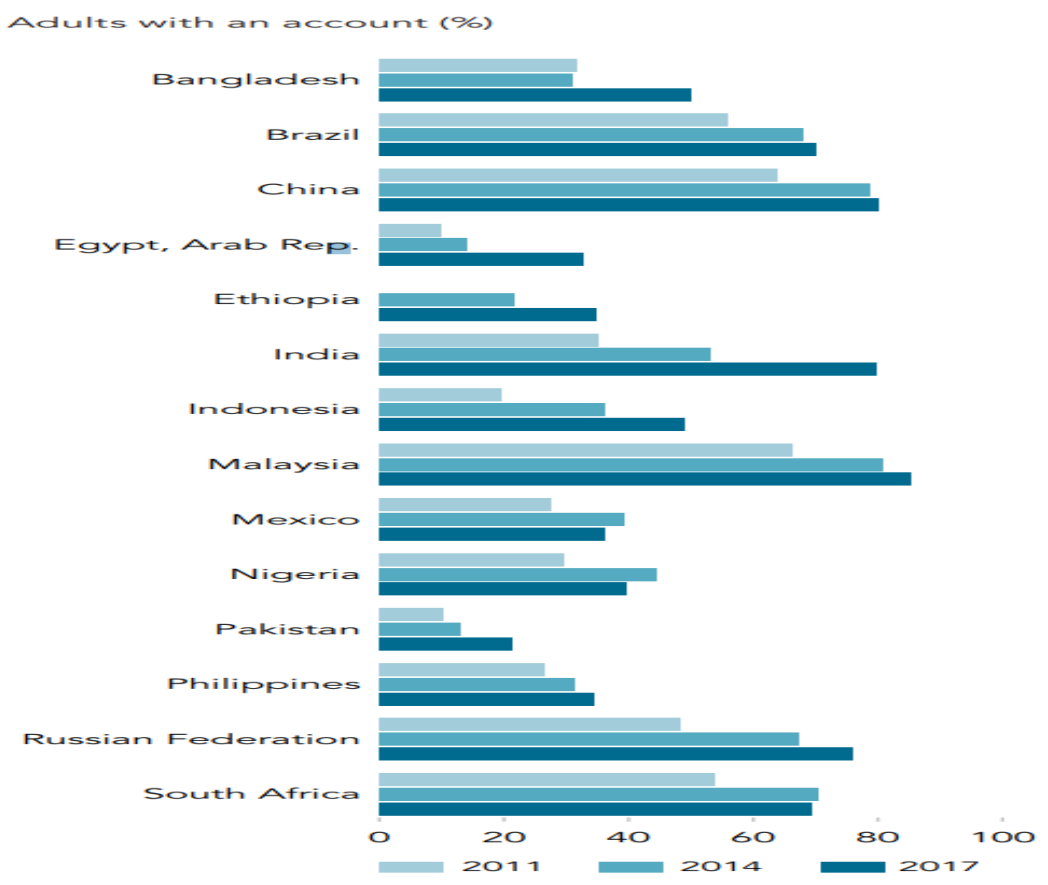




\section{Literature Review}

Our literature review is focused on the determinants of financial inclusion as well as the redistributive impact of macroprudential policies. The literature on financial inclusion uses several types of data to capture both the determinants and the effects of financial inclusion (Fowowe, 2017). It is important to highlight the findings on the links between financial inclusion and inequality, as well as inclusion and financial stability, as our questions lie within the core of those two strands when linking financial inclusion to macroprudential policies. ${ }^{16}$ We will briefly highlight the effects of financial inclusion, as well as the transmission channels - both direct and indirect - through which it affects financial stability and inequality. We will then review the literature on the determinants of financial inclusion.

\subsection{Transmission Channels between Financial Inclusion and Financial Stability}

1- Direct Channels: Financial inclusion can enhance the efficiency of financial intermediation by increasing both savings and the amount and value of transactions, improving investment cycles. The increased intermediation of domestic savings and the greater access to bank deposits boost the resilience of the deposit funding base of the banking sector, particularly during times of stress. This occurs by lowering the likelihood of correlated deposit withdrawals. Financial inclusion also improves banking sector liquidity (due to increased deposits) and lowers liquidity risks (Prasad, 2010, OCC, 2012, and Han and Melecky, 2013). All this improves the balance sheets of both households and corporates, as well as the banking sector.

2- Indirect Channels: Financial inclusion enhances the effectiveness of monetary policy, as a greater proportion of economic activity comes under the umbrella of the interest rate channel, and financial exclusion impedes the transmission mechanism of an inflation targeting policy, potentially lowering inflation (Mehrotra and Yetman, 2015, Lenka and Bairwa, 2016, and Brownbridge et A1., 2017). ${ }^{17}$ This is particularly significant as we argue that the effectiveness of macroprudential policies in financially underdeveloped markets is dampened, as financial inclusion levels are small in these economies. ${ }^{18}$ Also, since informal financial services could

\footnotetext{
${ }^{16}$ A detailed analysis of these links is beyond the scope of this chapter, but it well worth highlighting, to shed on the broader strands within which this chapter lies.

${ }^{17}$ Related to this is the argument of Granville and Mallick (2009) that inflation targeting is beneficial for financial stability.

${ }^{18}$ Along those lines, Boar et el. (2017) held that macroprudential measures are more effective if both financial development is sufficiently large.
} 
constitute a source of financial instability (Cull et Al., 2012), ${ }^{19}$ reducing access to such informal services may lead to lower financial instability.

It is important to note that the literature on between financial inclusion and financial stability is still in its infancy; an opposing, though less common view also exists, according to which increased inclusion reduces financial stability (Mehrotra and Yetman, 2015) if inclusion leads to rapid credit growth ${ }^{20}$. There is also the argument that the link between financial inclusion and financial stability depends on the measure of financial inclusion under consideration. ${ }^{21}$

\subsection{Determinants of Financial Inclusion}

The literature on financial inclusion highlights several types of data that capture the determinants - and effects - of financial inclusion (Fowowe, 2017). First, there are crosssectional studies that combine household or firm-level data with macroeconomic indicators of financial development, as well as inclusion (Demirguc-Kunt and Maksimovic, 1998, Beck et al., 2006 and 2008b, and Demirguc-Kunt et al., 2006). Second, there are country-specific studies that merge firm-level data and access data with financial development (Butler and Cornaggia, 2011 and Grima et al., 2008). Third, some studies use firm-level data ${ }^{22}$ on several indicators that capture access to financial markets (Beck et al., 2005, Ayyagari et al., 2008, Dinh et al., 2010, Aterido and Hallward-Driemeier, 2010, Aterido et al., 2011, and Fowowe, 2017). The first set of studies are of the highest interest; however, we touch upon some of the main findings of the other two sets, for reference purposes. Although the impact of financial inclusion is beyond the scope of this analysis, it is important to note that despite the recent increase in the research on this topic and the fact that financial inclusion is a top policy agenda, there is still an unclear link between financial inclusion and macroeconomic outcomes (Demirgüç-Kunt et al., 2017).

\footnotetext{
${ }^{19} \mathrm{Cull}$ et Al. (2012) give the example of pyramid schemes that are set up as means of informal savings and investment opportunities could trigger social, and political unrest, as well a lack of confidence in the traditional banking system, already a common characteristic among EMs, and frontier economies.

${ }^{20}$ Particularly if it leads to greater bank exposure to low quality/not creditworthy borrowers.

${ }^{21}$ For more information on the link between financial stability and financial inclusion, see Aiyar et al. (2016), Sahay et al. (2015), Morgan and Pontines (2014), and Lopez and Winkler (2016). The latter is particularly interesting as they show how financial inclusion could have helped moderate the credit crunch during the global financial crisis.

${ }^{22}$ Mainly from the World Bank - based on firm responses (Fowowe, 2017).
} 
Until recently, and mainly due to limited data availability, ${ }^{23}$ most empirical research focused on financial development ${ }^{24}$ rather than financial inclusion and income inequality. ${ }^{25}$ As the literature on the determinants of financial inclusion is still at a relatively early stage,${ }^{26}$ financial development was assumed automatically to lead to financial inclusion. This, however, is not necessarily the case. We argue that financial development is necessary but insufficient for financial inclusion. Relatedly, Evans (2015) holds that while financial development has increased over the last decade among African countries, the breadth and coverage of formal finance is still well below their peers. ${ }^{27}$ In this context, most studies on financial inclusion focus primarily on EMs, and frontier markets, using mainly country-specific data rather than crosscountry analysis. $^{28}$

Once again, financial inclusion and financial development are two distinct concepts, both of which are of huge importance, with existing overlaps. Financial inclusion is normally captured by ownership of an account by households (and enterprises,) either at a financial institution, or even through a mobile money service provider. ${ }^{29}$ Financial development, however, is measured by broader macro-level indicators that capture both bank and non-bank size, as well as health and efficiency of the financial sector. ${ }^{30}$ Financial development is also a necessary condition for financial inclusion, but is insufficient if financing constraints prevent households and firms from using the available financial services. Among the first studies to address the question of financial inclusion beyond the greater scope of financial development was that of Beck et al. (2007b). Using data for banking sector outreach ${ }^{31}$ for 99 countries over the period 2003-2004, they found that institutional quality affects financial inclusion positively, while the degree of

\footnotetext{
${ }^{23}$ Data collection efforts on financial inclusion began around 2004 (Demirgüç-Kunt et al., 2017)

${ }^{24}$ Financial development is a process by which funds are efficiently channelled from savers to borrowers, by reducing information, and transaction costs. A lot of work during the last decade has attempted to measure financial development. For more information, see the World Bank (2008). Common indicators that have been used to capture financial development typically cantered on indicators related to financial depth, and efficiency. For more information on financial development, and how it is measured, see World Economic Forum (2008)

${ }^{25}$ For more information, see King and Levine 1993; Beck et al. 2000; Clark et al. 2006; Beck et al. 2007; Demirguc-Kunt and Levine, 2009.

26 The more common strand of literature focuses on financial development, while access is lumped as part of it.

${ }^{27}$ Other EMs and frontier markets.

${ }^{28}$ As is more commonly the case, with the broader literature on financial development.

${ }^{29}$ Demirguc-Kunt (2017) elaborates further that accounts can be either a deposit or transaction account to be used to make and receive payments, store, and save money. Inclusion as such also includes access to credit for borrowing purposes, and the use of insurance products to better manage financial risks.

${ }^{30}$ For a comprehensive list of variables comprising financial development, see the World Economic Forum (2008). Financial development generally refers to the size and depth of an economy's financial markets, both banks and non-banks (equity, bond markets, insurance markets, as well as shadow banks as examples).

${ }^{31}$ Covering both access and use of financial services indicators.
} 
government ownership of banks has a negative effect. ${ }^{32} 33$ Other determinants of financial inclusion include GDP per capita, governance, and the institutional quality and the regulatory environment. (Rojas-Suarez, 2010, Karlan et al., 2013, Park and Mercado, 2015, and Allen et al., 2016,).

Some of the most interesting studies on the determinants of financial inclusion include that of Sarma and Pais (2008), who employ data for 49 countries to study the determinants of financial inclusion. They find that higher GDP per capita, physical infrastructure ${ }^{34}$, telephone and internet subscriptions, financial development, and adult literacy have a positive and significant impact on financial inclusion. However, a higher percentage of rural population, a high share of foreign bank ownership, non-performing loans, as well as highly capitalized banking systems - as measured by the capital asset ratio (CAR) - were inversely associated with financial inclusion. The authors conclude that there is an element of cautiousness associated with lending when it comes to banks with a high CAR.

Honohan (2008) uses financial access data for 160 countries within an OLS context and finds that increased mobile phone penetration ${ }^{35}$ and better institutional quality (as well as governance) are positively correlated with their access variables - the number of bank accounts per 100 adults - even when per capita income is controlled for. Another important factor is greater proximity to financial intermediaries, which could also be in line with Honohan and King's (2009) result that mobile phone penetration matters for higher household financial penetration ratios. Generally, levels of economic development and financial inclusion are highly correlated (Sarma and Pais 2011), suggesting that for more developed economies, fewer unbanked households ${ }^{36}$ are to be expected.

Gimet and Lagoarde-Segot's (2012) study examines the link between financial development and access to finance, and specifically whether banking and capital market characteristics can increase banks' ability to increase credit to the private sector while boosting financial inclusion. Using data for 138 countries over the period 2002-2009, they employed GMM and panel vector error correction models. ${ }^{37}$ They found that financial development - evidenced by more

\footnotetext{
${ }^{32}$ Other control variables that had a positive impact on inclusion - or outreach as the authors refer to it - have been the log of GDP per capita, as well as indicators capturing infrastructure, and communications (telephone mainlines).

${ }^{33}$ However, Demirguc-Kunt et al. (2015) highlight the role that governments can play in fostering financial inclusion, by transforming government payments from cash into bank (and ever more recently into mobile) accounts.

${ }^{34}$ Such as a country's network of paved roads.

${ }^{35}$ Related to this is the rising literature on the role of digital payments in raising income and promoting financial inclusion. For more information, see Beck (2016).

${ }^{36}$ Or more financial inclusion, and less financial exclusion.

${ }^{37}$ Credit results are beyond the scope of this chapter, so we only report the financial inclusion related results.
} 
developed equity markets - increases access to finance as they offer opportunities for banks to develop tools to increase access to their supply and services. They also found that a larger banking sector size hinders access to finance, and smaller banks with strong proximity to their clients are better for financial inclusion. The health, as well as efficiency of the banking sector is hugely important in terms of access to finance, particularly lower NPLs and higher bank capital to asset ratio, and lower fees on deposit accounts. Institutional quality was also found to be a determinant for access to finance, and they found that an increase in Tier 1 bank capital asset ratio had a negative impact on credit. This implied that while higher capital requirements were effective in lowering credit boom related vulnerabilities, lower credit expansion meant lower financial inclusion. It is very important to note that Gimet and Lagoarde-Segot's (2012) paper is one of the few - to our knowledge - that linked financial inclusion to macroprudential policy. Beyond capital market development, the authors find that macroprudential regulation ${ }^{38}$ (as measured by tier 1 banking capital asset ratios as a proxy for capital requirements) is important for financial stability; however, it lowers financial inclusion, via lower credit extensions.

Another strand of the literature on financial inclusion focuses on country or region-specific studies. Pal and Pal (2012) employed maximum likelihood in the 35 States and Union Territories in India, and found that per capita income is an important determinant of households' propensity to use formal financial services. They also found that the increased availability of banking services boosts financial inclusion, especially among the poor. Other determinants of financial inclusion include education, employment status, and household size. In particular, household income and employment status have the strongest effect on financial inclusion in urban areas in India.

Fungáčová and Weill (2015) use the 2011 World Bank Global Findex database to study the determinants of financial inclusion in China, compared to other BRICS countries. They find that higher income, improved education, and being an older male are linked to an increased use of formal accounts and formal credit in China. Educational attainment and income tend to affect the use of alternative sources of borrowing. ${ }^{39}$ Tuesta et al. (2015) used a series of probit

\footnotetext{
${ }^{38}$ The authors held that more regulation is important to lower the likelihood of boom-bust cycles, especially in credit lending. A $1 \%$ increase in tier 1 banking to capital asset ratio has an adverse impact on credit, Thus increases in capital requirements while efficient in lowering credit boom related vulnerabilities - lower credit growth.

${ }^{39}$ Borrowing from friends and family, borrowing from an employer, or another private lender.
} 
models ${ }^{40}$ to study the determinants of financial inclusion in Argentina, and found that the level of education, income, and age are all important determinants of inclusion.

Oyelami et al. (2017) studied the determinants of financial inclusion in Sub-Saharan Africa using Panel Autoregressive Distributed Lags (ARDL), and their proxy for financial inclusion were 1) depositors with commercial banks per 1,000 adults, and 2) borrowers from commercial banks per 1,000 adults. They found that financial inclusion is significantly influenced by both supply and demand side factors. Demand side factors include the level of income and literacy (primary school enrolment), while the supply side factors are the interest rates (both deposit and lending), and ATM usage as a proxy for bank innovation. GDP per capita was not found to have a positive impact on financial inclusion, which contradicts some of the earlier findings in the literature (Honohan and Beck,2007) and Sarma \& Pais, 2011 for example). ${ }^{41}$

The determinants of financial inclusion in advanced economies have only recently become a subject of interest among policy makers and academics. Ampudia, and Ehrmann (2017) use household-level data for 14-euro area countries and the US, over the period 2009-2010, to study the determinants and effects of being unbanked in these areas. Using a probit model and a propensity score matching approach, they find that financial exclusion is common among lowincome, unemployed households, as well as households with low education. They also find that being banked significantly increases net wealth compared to those unbanked, with a gap of around $€ 74,000$ for the euro area, and USD 42,000 for the United States. ${ }^{42}$ Education, lower unemployment, and government policies that encourage the recipients of transfer payments to open bank accounts were found to be contributing to financial inclusion.

\section{DATA}

Our analysis addresses financial inclusion using both measures that capture access to, and usage of, financial services. For variables related to financial access, we focus on ownership of an account, availability of bank branches, and ATM machines. We also capture access using variables that combine access to financial markets and financial institutions, as calculated by the IMF's Financial Development Database (Svirydzenka, 2016), as a broader measure of

\footnotetext{
${ }^{40}$ The authors hold that probit models allow the analysis of existing correlations between financial inclusion and certain variables of interest.

${ }^{41}$ Other control variables GDP per capita, CPI, institutional quality, trade openness (sum of exports and imports as a share of GDP) to capture the degree of international openness, and a measure of human capital captured by the logarithm of gross secondary enrolment rate (Zahonogo, 2017)

${ }^{42}$ This wealth difference is potentially caused by the fact that banked households are have a significantly higher potential to accumulate wealth by owning their primary residence.
} 
financial access reflecting access to bond and equity markets. The IMF's Financial Development Database includes bank branches and ATMs as their proxy for financial institutions access, while financial markets access is proxied by the percentage of market capitalization outside of the top 10 largest companies and the total number of issuers of debt (see Table 3 in Annex I for further details). For variables related to usage of financial services, we use the number of borrowers and depositors with commercial banks per 1000 adults.

We follow the literature for our explanatory variables and include the unemployment rate, education (proxied by secondary enrolment), urbanization, and openness in our baseline regressions. We also include a host of additional explanatory variables for robustness purposes. For our macroprudential variables, we follow Cerutti et al. (2015) and Shim et al. (2013) to capture the various macroprudential tools and their usage within a loosening and tightening context. Cerutti et al. (2015) use dummy variables to reflect the usage (1) of macroprudential policies versus their absence (0). Shim et al. (2013) use a positive scale to capture the number of tightening instances ( 2 for example, if the macroprudential tool of interest was tightened twice in the period of interest), a negative number to present a loosening instance $(-3$, if there were three loosening instances), and 0 if there was no change. We supplement those databases with actual data on reserve requirements and provisioning to capture the magnitude of change of those two macroprudential policies rather than simply the use of dummy variables. The full list of macroprudential variables are presented in Table 4 in Annex I, reflecting the 32 measures employed. ${ }^{43}$

The dataset is constructed as a cross-country panel ${ }^{44}$ using annual data over the period 20002014. Beyond the macroprudential tools and the IMF Financial Development Database, the rest of our dependent variables and explanatory variables are obtained from the World Development Indicators database and the World Bank Financial Access Survey. The data set includes 67 AEs and EMs; ${ }^{45}$ Table 1 in Annex I provides the list of countries included in the sample.

\footnotetext{
${ }^{43}$ The 32 measures are not distinct. Most of those from Shim et al. (2013) are included in Cerutti's (2015) database, but the former reflects instances of tightening and loosening, while the latter only has dummies to reflect their usage. We supplement these with actual RRRs to reflect the magnitude of changes in RRRs and their impacts. A similar effort was conducted for the collection of LTV ratios and provisioning, but data inconsistencies (including short time series availability) yielded inconclusive results for these variables.

${ }^{44}$ We also have cross-sectional results using ordinary least squares, and two staged least squares, but we focus on panel regressions in this chapter.

${ }^{45}$ We are cognizant that data on macroprudential regulation on frontier markets are not commonly available and most of them get dropped out of the sample, out of an original sample including 114 countries and an extensive effort to collect data on macroprudential policies for these countries. Robustness checks are thus only conducted for AEs and EMs.
} 


\section{Model Specification and Methodology}

The analysis of the relationship between macroprudential policies and financial inclusion is divided into two parts. First, we study the impact of the usage of various macroprudential policies on financial inclusion using measures to reflect access and usage of financial services. Second, we examine how financial development and institutional quality affect the relationship between macroprudential policies and financial inclusion.

To analyze the impact of macroprudential policies, the following dynamic panel regression model of financial inclusion is used:

$$
\begin{gathered}
\text { FinClusion }_{i, t}=\alpha+\rho \text { FinClusion }_{i, t-1}+\beta \mathrm{X}_{\mathrm{i}, \mathrm{t}}+\text { STool }_{\mathrm{i}, \mathrm{t}}+\varepsilon_{\mathrm{i}, \mathrm{t}} \\
i=1,2, \ldots \mathrm{N}, t=2000, \ldots \mathrm{T}
\end{gathered}
$$

where FinClusion $_{i, t}$ denotes the financial inclusion variable of interest as described below, FinClusion $_{i, t-1}$ is the autoregressive (lag) term of order one,${ }^{46} \mathrm{X}_{\mathrm{it}}$ is the matrix of independent variables which includes the unemployment rate (\%), urban population ( $\%$ of total population), secondary school enrolment (\% of gross), and openness. The variable $T_{0 o} l_{\text {it }}$ represents the different macroprudential tools used by country $i$ at time $t$, with variables such as the RRR, the LTV ratio, DTI ratio used inter-changeably to capture the impact of macroprudential policies, and $\varepsilon_{i t}$ is the error term of the regression.

Our first measure of FinClusion $_{i, t}$ is the principal component of the IMF's Financial Institutions Access variable and the Financial Markets Access variable as defined by Svirydzenka (2016) in the IMF's index of financial development. In this case, Financial Institutions Access is a proxy of bank branches per 100,000 adults and ATMs per 100,000 adults, while Financial Markets Access is a proxy of the percentage of market capitalization outside of the top-10 largest companies and the total number of issuers of debt (domestic, external, financial, and non-financial corporations). This variable aims to capture the ability of households and corporates to access financial services (Svirydzenka, 2017).

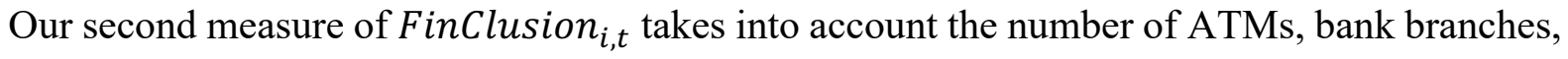
and bank accounts, ${ }^{47}$ by solely focusing on access to financial institutions irrespective of financial markets, which was already captured in our first measure. To capture usage of financial services, our third measure of FinClusion $_{i, t}$ include measures that capture borrowers

\footnotetext{
46 Lagged values are included to account for causality.

${ }^{47}$ Also, calculated as the Principal Component Analysis of ATMs, bank branches, and bank accounts.
} 
and users. Specifically, we compute the principal component of borrowers at commercial banks per 1,000 adults, and depositors at commercial banks per 1,000 adults. We then re-estimate the equation for depositors and borrowers separately to understand the determinants of each variable separately. We thus end up with five dependent variables all of which capturing financial inclusion. ${ }^{48} \mathrm{We}$ include the principal component of borrowers and depositors to capture usage of financial services broadly, in line with financial access.

The hypothesis tested here is that macroprudential policies significantly affect financial inclusion. In other words, a macroprudential tightening (loosening) for country $i$ will affect the different types of financial inclusion in our panel. Using the datasets from Cerutti et al. (2015), Shim et al. (2013), as well as actual data for the reserve requirements, we test for the effectiveness of a total of 32 macroprudential tools that capture the presence of macroprudential policies, as well as the ways in which they operate (in a tightening vs. loosening manner).

For our panel regression, Equation 1 and its variations - using alternative dependent variables - will be estimated using the dynamic panel system General Method of Moments estimator (GMM) proposed by Arellano and Bover (1995), Blundell and Bond (1998), and Blundell, Bond, and Windmeijer (2000). The Ordinary Least Squares (OLS) and the Least Square Dummy Variable (LSDV) estimators cannot be used in the case of a dynamic panel data model. This is because the former would result in biased estimators, while the latter would result in inconsistent estimators (Hsiao, 2003). More specifically, the presence of a lagged endogenous variable suggests that correlation will exist between it and the error term, resulting in biased estimators; there is thus strong evidence suggesting that financial inclusion depends on its lags. Therefore, and as the GMM circumvents correlation problems (Yaffee, 2003), it will consistently estimate the dynamic panel data model (Kitazawa, 2003).

To overcome the bias problems of the difference GMM methodology, it is important to follow Caselli, Esquivel and Lefort (1996), Holtz-Eakin, Newey and Rosen (1988) and Arellano and Bond (1991). We estimate Equation 1 using the dynamic panel System GMM, as elaborated by Arellano and Bover (1995), Blundell and Bond (1998), and Blundell, Bond, and Windmeijer (2000). ${ }^{49}$ This is achieved by combining the standard set of moment conditions in first-

\footnotetext{
${ }^{48}$ Once again, our dependent variables are 1) Principal component of financial markets access and financial institutions access; 2) principal component of ATMs, bank branches, and bank accounts to capture access only to financial institutions; 3) principal component of borrowers and depositors with commercial banks to capture usage of financial services; 4) depositors with commercial banks per 1000 adults, and 5) borrowers from commercial banks per 1000 adults. Variables 4 and 5 comprise variable 3 .

${ }^{49}$ Other papers examining financial inclusion - within a financial stability context - that also employed System-GMM include Pontines and Morgan (2014).
} 
difference and lagged levels as instruments with an additional set of moments conditions derived from the equation in levels. Thus, removing the unobserved fixed effects, we take the first difference of Equation 1 as follows:

$$
\begin{aligned}
\text { FinClusion }_{i, t} & \left.- \text { FinClusion }_{i, t-1}\right) \\
& =\alpha+\rho\left(\text { FinClusion }_{i, t}-\text { FinClusion }_{i, t-1}\right)+\beta\left(\mathrm{X}_{\mathrm{i}, \mathrm{t}}-\mathrm{X}_{\mathrm{i}, \mathrm{t}-1}\right)+\delta\left(\text { Tool }_{\mathrm{i}, \mathrm{t}}\right. \\
& \left.- \text { Tool }_{\mathrm{i}, \mathrm{t}-1}\right)+\left(\varepsilon_{\mathrm{i}, \mathrm{t}}-\varepsilon_{\mathrm{i}, \mathrm{t}-1}\right)
\end{aligned}
$$

Within the literature of financial development and access, Zahongo (2017) highlights the importance of using System GMM as a way to control for country specific effects and the endogeneity issue that may arise between the control variables and the endogenous variables (poverty, in their case). Ahamed and Mallick (2017) highlight the importance of using system GMM in this context, where the lagged variables are used as instruments, thus optimizing the efficiency of the estimates with more moment conditions. Furthermore, the System GMM methodology assumes that the correlation between the dependent variable and the error term and the set of the independent variables and the error term is as follows:

$$
\begin{gathered}
E\left[\Delta \text { FinClusion }_{i, t}, \varepsilon_{i, t}\right]=0, \text { For } t=2, \ldots, T \\
E\left[\Delta X_{i, t} \varepsilon_{i, t}\right]=0, \text { For } t=2, \ldots, T
\end{gathered}
$$

where $X_{i, t}$ is the set of all the explanatory variables of Equation (1). In this context, this methodology offers a vigorous solution to the endogeneity bias, while being more rigorous in terms of measurement errors relative to cross-sectional regressions. Moreover, it continues to be consistent in spite of the possibility of endogenous explanatory variables, since $E\left[X_{\mathrm{t}} \varepsilon_{\mathrm{s}}\right] \neq 0$ for $s \leq t$, if the instrumental variables are appropriately lagged (Pontines and Morgan, 2014). The Arellano-Bond test for autocorrelation is reported under each table. The null hypothesis assumes no autocorrelation, and the test for $\operatorname{AR}(2)$, which is normally more important, as it detects autocorrelation in levels (Neaime and Gaysset, 2018). We also check both the Sargan and Hansen tests to confirm that our model is correctly specified.

Given the varying levels of institutional quality and financial development between AEs and EMs, we divide into two groups based on the IMF country definition of AEs and EMs, to see how the results differ. Furthermore, we re-estimate Equation 1 and its variations by introducing measures of financial development and institutional quality ${ }^{50}$ interacted with macroprudential

\footnotetext{
${ }^{50}$ We only report the interacted terms between financial development and the various macroprudential tools, as well as the governance and macroprudential tools, as this is our main interest rather than the coefficient of each variable alone.
} 
policies. This will help us understand how the results would differ in the presence of those two factors. Thus, Equation 1 will be re-estimated, also using System GMM, as follows:

$$
\begin{gathered}
\text { FinClusion }_{i, t}=\alpha+\rho \text { FinClusion }_{i, t-1}+\beta \mathrm{X}_{\mathrm{i}, \mathrm{t}}+\delta \text { Tool }_{\mathrm{i}, \mathrm{t}}+\vartheta\left(\text { FinDev }_{\mathrm{i}, \mathrm{t}} * \text { Tool }_{\mathrm{i}, \mathrm{t}}\right) \\
+\varepsilon_{\mathrm{i}, \mathrm{t}}
\end{gathered}
$$

FinDev $_{i, t}$ in Equation 4 is our measure of financial development, calculated as a principal component of two variables that comprise the financial depth and financial efficiency within a country's institutions and markets. These have been obtained from the IMF (2017) Financial Development Database. The Financial Depth indicator is a proxy for financial depth within financial institutions and financial markets, and is comprised of private sector credit to GDP, pension fund assets to GDP, mutual fund assets to GDP, stock market capitalization to GDP, stocks traded to GDP, international debt securities of government to GDP, total debt securities of financial corporations to GDP, and total debt securities of non-financial corporations to GDP. The financial institutions efficiency indicators reflects efficiency also within financial institutions and financial markets, and is a proxy of the net interest margin, lending-deposits spread, non-interest income to total income, overhead costs to total assets, return on assets, return on equity., and the stock market turnover ratio (stocks traded to capitalization). The IMF Financial Development Database provides an aggregate measure for financial institutions depth, financial institutions efficiency, as well as financial markets depth and efficiency. Once again, we calculate their principal component analysis; all of them should represent a country's level of financial development.

For institutional quality, we implement a principal component analysis to capture the World Bank's six governance indicators that we use as a proxy for institutional quality. Variables in this database include rule of law, political stability, government effectiveness, voice and accountability, regulatory quality, and control of corruption.

After conducting our System GMM estimations for equations 4 and 5, we report the total effect of governance and financial development, to capture the impact of macroprudential policies in the presence of either improved governance or financial development. This is estimated by 
adding up the coefficient $\delta$ to the coefficient $\vartheta$, in equations 4 and 5 above, and their statistical significance is determined by their variances and covariances.

\section{Results}

Once again, we employed a total of 32 macroprudential policies- capturing their usage, as well as instances of loosening/tightening- to test for their impact on financial inclusion. ${ }^{51} \mathrm{We}$ examined several aspects of financial inclusion to capture both financial access and usage of financial services. We begin by highlighting our baseline regressions for the full sample, then we outline our results after splitting the sample into AEs and EMs, and then we proceed to discuss the role of institutional quality, proxied by governance indicators, and financial development in affecting the role of macroprudential policies.

\subsection{Baseline Regression Results}

Macroprudential policies yielded mixed results in terms of their impact on financial inclusion, with a number of insignificant results. In this section, we only report the macroprudential policies that yielded significant results - either positive or negative - on financial inclusion. ${ }^{52}$ Tables (1) and (2) summarize ${ }^{53}$ the impact of the various macroprudential tools on financial inclusion - both access and usage.

Table (1): Summary of Results: Access to Financial Services

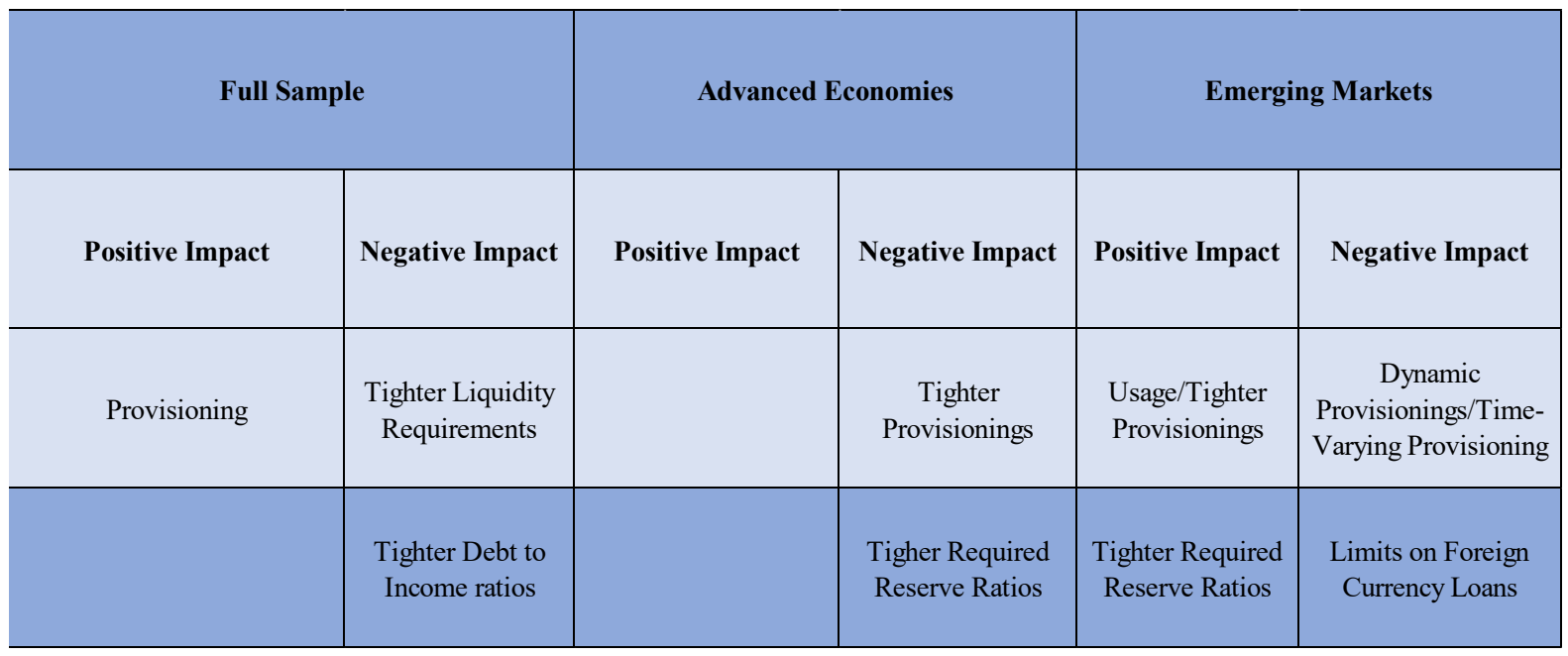

In terms of access, the use of provisioning as a macroprudential tool is the only tool that has a positive impact on access to financial services, within our entire sample, while tighter liquidity requirements and debt to income ratios lowered financial access. On dividing our sample

\footnotetext{
${ }^{51}$ The full list of macroprudential tools and a description of how they operate is available in the Annex to this chapter.

52 The rest of our results - the insignificant ones - are available upon request. This is done in the interest of time/space.

${ }^{53}$ This table - and this section as a whole - only displays the significant results for our regressions. Additional results of the full (and insignificant) are available in the annex.
} 
between AEs and EMs markets, we see a slightly different pattern. For AEs, with already high levels of financial inclusion - and financial development overall - macroprudential policies do not contribute to increased financial access - captured by increased accounts, branches, or ATM machines, an expected result. Tighter provisioning, and tighter RRRs lowered access, however, in this case.

For EMs, dynamic provisioning appeared to reduce financial access, while provisioning ${ }^{54}$ and RRRs increased access. ${ }^{55}$ One striking observation is that both provisioning and RRRs had a positive impact on financial access in EMs, and an adverse impact on access in AEs. Given the different levels of financial access - and broader financial development - between EMs and advanced economies, we thus are seeing differences in the results between both sub-groups. One broad conclusion we can draw from these results is that macroprudential policies in EMs - which tend to be financially underdeveloped - improves access, and it decreases it in AEs, with already high levels of access and financial intermediation.

In terms of usage, Table (2) shows that most of the macroprudential policies employed had a positive impact on usage of financial services across our full sample- both in terms of the number of borrowers and depositors- and upon dividing our sample into EMs and AEs. For the full sample, only taxes imposed on financial institutions only adversely affected the number of borrowers. This could be a result of the fact that financial institutions pass on the additional taxes as fees on borrowers. For AEs, borrower-Targeted Instruments (LTV ratios and debt to income ratios) positively affected usage of financial services, particularly depositors. No instrument appeared to adversely affect the usage of financial services among AEs. For EMs, tighter weights, and the use of RRRs had a positive impact on the usage of financial inclusion, while LTV caps, and dynamic provisioning lowered the usage of financial services.

\footnotetext{
${ }^{54}$ If not applied countercyclically.

${ }^{55}$ Similar to Pearlman (2015).
} 
Table (2): Summary of Results: Usage (Borrowing and Depositing) of Financial Services

\begin{tabular}{c|l|l|l|l|l|}
\hline \multicolumn{2}{|c|}{ Full Sample } & \multicolumn{2}{c|}{ Advanced Economies } & \multicolumn{2}{c|}{ Emerging Markets } \\
\hline Positive Impact & Negative Impact & Positive Impact & $\begin{array}{c}\text { Negative } \\
\text { Impact }\end{array}$ & Positive Impact & $\begin{array}{c}\text { Negative } \\
\text { Impact }\end{array}$ \\
\hline $\begin{array}{c}\text { Provisioning; Limits on } \\
\text { Domestic Currency } \\
\text { Loans; Financial- } \\
\text { Institutions Targeted } \\
\text { Instruments (Aggregate } \\
\text { Index) }\end{array}$ & $\begin{array}{c}\text { Taxes (adversely } \\
\text { affects borrowers) }\end{array}$ & $\begin{array}{c}\text { Instruments (Aggregate } \\
\text { Index) }\end{array}$ & Borrower Targeted & $\begin{array}{c}\text { Tighter Reserve } \\
\text { Requirements/Usage } \\
\text { of RRRs }\end{array}$ & LTV Caps \\
\hline $\begin{array}{c}\text { Tighter/Countercyclical } \\
\text { Reserve } \\
\text { Requirements/Usage of } \\
\text { RRRs (Domestic or } \\
\text { FX); }\end{array}$ & & & & $\begin{array}{c}\text { Tighter Risk } \\
\text { Weights }\end{array}$ & Pynamic \\
\hline $\begin{array}{c}\text { Tighter Taxes } \\
\text { (positively affects } \\
\text { Depositors) }\end{array}$ & & & & & \\
\hline
\end{tabular}

We now proceed to analyze the abovementioned results in more detail. Table (3) presents our baseline regression with the dependent variable, Financial Access ${ }^{56}$, which captures the ability of both individuals and enterprises to access financial services. Once again, this variable is the principal component of the IMF's Financial Institutions Access variable and Financial Markets Access variable to capture the ability to access the different financial institutions and market within an economy. Column (1) shows our baseline regression where Financial Access is regressed on its lag, which as expected is positive and significant at the $1 \%$ level. The unemployment rate displays a negative relationship, also as expected with financial inclusion, whereby a $1 \%$ increase in unemployment lowers financial access by $0.1-0.2 \%$. This is a similar result to Ampudia, and Ehrmann (2017) whereby unemployment increases financial exclusion. Both urbanization and secondary enrolment exert a positive and significant impact on financial inclusion, although their magnitude is small. Openness - contrary to the literature (Zahonogo, 2017) has a negative and significant impact on financial inclusion, but in only one of the regressions in this table.

\footnotetext{
${ }^{56}$ Financial access and inclusion will be used interchangeably in this section.
} 
The tightening of the debt to income ratio and the liquidity ratios lowered financial inclusion, shown in Columns (2) and (3). Any variable preceded by LT (Loosening/tightening) represents a variable that captures the change in the policy tools as described by Shim et al. (2013). Specifically, we find that a one-notch tightening in the debt-to-income ratio - which normally happens to restrict the provision of housing credit - lowers financial inclusion by $0.9 \%$. The idea behind this tool is that financial authorities stipulate either 1) a specific percent of the borrower's monthly income as the maximum amount of monthly repayments on a home loan; 2) a specific multiple of the household's income as the minimum debt-service - to-debt ratio; or 3) a shortening of the maturity of mortgage contracts or abolishing any preferential interest rates for mortgage loans (Shim et al., 2013). This result supports Shim et al's (2013) argument any of the above-mentioned actions that would raise (or tighten) the debt to income ratio, raises the debt repayments of borrowers, which forces them to borrow less. We also find that a one notch tightening in the liquidity requirement - the minimum ratio for highly liquid assets that ensure that banks can endure episodes of severe cash outflows in situations of distress in Column (2) also lowers financial inclusion by $1 \%$.

Similarly, tighter liquidity appears to have a slightly larger impact on inclusion, whereby a one notch tightening in the liquidity ratio reduces financial inclusion by $1 \%$. Generally, tighter liquidity requirements imply that banks are required to hold an adequate stock of high quality liquid assets to mitigate instances of distressed funding, which could adversely affect the volume of lending (Berben et al., 2010). ${ }^{57}$ Column (4) introduces a measure that captures the dynamic provisioning, which shows that tighter provisioning - when introduced in a countercyclical manner - increases financial inclusion. ${ }^{58}$ Thus, as dynamic provisioning reduces the procyclicality in the financial sector (Fernandez de Lis and Garcia-Herrero, 2010), the higher the financial inclusion, by $0.6 \% .{ }^{59}$ Columns (2), (3), and (4) show that the statistical significance of the other explanatory variables - except for openness - is preserved with the introduction of macroprudential tools.

\footnotetext{
${ }^{57}$ Ultimately affecting access to finance.

${ }^{58}$ Recall that the conventional loan-loss provisioning is tied to loan delinquency, and that implies that in good times, the banking sector does not to need to hold provisions, while in bad times, they need to increase provisioning once delinquencies appear. Traditionally, this lowers their available capital and their ability to extend lending (Fernandez de Lis and GarciaHerrero, 2010).

${ }^{59}$ All other measures in Table (1) are not significant.
} 
Table (1): Financial Inclusion \& Macroprudential Policy

Dependent variables: Finacc1=Financial Access Variable (PCA of Financial Markets Access and Financial Institutions Access to capture overall access within an economy); Finacc2= Financial Access Variable (PCA of Bank Branches, Accounts, and ATMs per 100,000 people; \% of Adults)

Estimation Method: Arellano-Bover/Blundell-Bond Dynamic Panel System GMM

\begin{tabular}{|c|c|c|c|c|c|}
\hline VARIABLES & $\begin{array}{c}(1) \\
\text { Finacc1 }\end{array}$ & $\begin{array}{c}(2) \\
\text { Finacc1 } \\
\end{array}$ & $\begin{array}{c}(3) \\
\text { Finacc1 }\end{array}$ & $\begin{array}{c}(4) \\
\text { Finacc1 }\end{array}$ & $\begin{array}{c}(5) \\
\text { Finacc2 }\end{array}$ \\
\hline $\operatorname{AR}(1)$ & $\begin{array}{c}0.950 * * * \\
(0.0175)\end{array}$ & $\begin{array}{l}0.931 * * * \\
(0.0244)\end{array}$ & $\begin{array}{c}0.949 * * * \\
(0.0141)\end{array}$ & $\begin{array}{c}0.939 * * * \\
(0.0154)\end{array}$ & $\begin{array}{c}0.956^{* * *} \\
(0.0171)\end{array}$ \\
\hline Unemployment & $\begin{array}{c}-0.00136^{* * *} \\
(0.000492)\end{array}$ & $\begin{array}{c}-0.00134^{* *} \\
(0.000658)\end{array}$ & $\begin{array}{c}-0.00134^{* *} \\
(0.000618)\end{array}$ & $\begin{array}{c}-0.00143 * * * \\
(0.000428)\end{array}$ & $\begin{array}{c}0.382 \\
(0.354)\end{array}$ \\
\hline Secondary enrolment & $\begin{array}{c}0.000257 * * \\
(9.94 \mathrm{e}-05)\end{array}$ & $\begin{array}{l}0.000301^{*} \\
(0.000162)\end{array}$ & $\begin{array}{c}0.000210 \\
(0.000141)\end{array}$ & $\begin{array}{c}0.000359 * * * \\
(0.000112)\end{array}$ & $\begin{array}{l}0.0405 \\
(0.101)\end{array}$ \\
\hline Urbanization & $\begin{array}{c}0.000247 * * \\
(0.000111)\end{array}$ & $\begin{array}{c}0.000336^{* * *} \\
(0.000142)\end{array}$ & $\begin{array}{c}0.000341 * * \\
(0.000131)\end{array}$ & $\begin{array}{c}0.000198 \\
(0.000134)\end{array}$ & $\begin{array}{c}-0.00815 \\
(0.118)\end{array}$ \\
\hline Openness & $\begin{array}{l}-3.19 \mathrm{e}-05 \\
(2.32 \mathrm{e}-05)\end{array}$ & $\begin{array}{c}1.28 \mathrm{e}-05 \\
(3.11 \mathrm{e}-05)\end{array}$ & $\begin{array}{l}-1.88 \mathrm{e}-06 \\
(2.38 \mathrm{e}-05)\end{array}$ & $\begin{array}{l}-2.75 \mathrm{e}-05 \\
(2.18 \mathrm{e}-05)\end{array}$ & $\begin{array}{l}0.164 * * * \\
(0.0522)\end{array}$ \\
\hline It_liquidity & & $\begin{array}{l}-0.0102 * \\
(0.00598)\end{array}$ & & & \\
\hline 1t_DTI & & & $\begin{array}{l}-0.00935 * \\
(0.00515)\end{array}$ & & \\
\hline lt_Provisioning & & & & & \\
\hline Dynamic provisioning & & & & $\begin{array}{l}0.00652 * \\
(0.00360)\end{array}$ & \\
\hline Provisioning & & & & & $\begin{array}{c}0.0932 * * * \\
(0.0343)\end{array}$ \\
\hline Observations & 950 & 542 & 542 & 661 & 234 \\
\hline Number of code & 100 & 55 & 55 & 81 & 43 \\
\hline Arellano-Bond Test & & & & & \\
\hline Order $1 \mathrm{p}$-value & 0.000 & 0.000 & 0.000 & 0.000 & 0.171 \\
\hline Order $2 \mathrm{p}$-value & 0.879 & 0.889 & 0.927 & 0.710 & 0.724 \\
\hline
\end{tabular}

Standard errors in parentheses; ${ }^{* * *} \mathrm{p}<0.01,{ }^{* *} \mathrm{p}<0.05,{ }^{*} \mathrm{p}<0.1$; LT refers to loosening/tightening of macroprudential tools from Shim et al's $(2013)$ Database 
The estimation results of the Hansen test for all the estimation tables confirm that the p-value is large, ensuring the validity of the overidentifying restrictions, and cannot be rejected. These results warrant the correct selection of instruments in such a way that they are not correlated with the error term. The results also confirm that there are no issues of omitting imperative variables from the model, ensuring that the chosen models are correctly specified.

Column (5) introduces an alternative financial inclusion measure that is comprised of the principal component analysis of bank branches, ATM machines, and accounts. It is a pure focus on access to financial institutions, whereas the other columns include access to financial markets as well. This time, the significant variable captures provisioning, a similar result to the other columns; provisioning as a macroprudential tool is found to increase financial inclusion by $9 \%$ (relative to $0.6 \%$ in the other columns) suggesting the importance of provisioning for financial access within the banking sector, more so than within financial markets.

Table (2) introduces an alternative measure of financial inclusion representing the usage of financial services. This variable represents the principal component of borrowers and depositors (per 1000 adults) within the financial system. In line with the results in table (1), it shows that a one notch tightening in provisioning increased usage of financial services by $22 \%$. All other financial inclusion measures were not significant.

Table (2): Usage of Financial Services \& Macroprudential Policy

Dependent variable: Depositors and Borrowers from the Banking Sector (Principal Component Analysis of Both depositors and borrowers with commercial banks per 1000 adults)

Estimation Method: Arellano-Bover/Blundell-Bond Dynamic Panel System GMM.

\section{(7)}

\begin{tabular}{lc} 
VARIABLES & \\
\hline & $1.016^{* * *}$ \\
AR(1) & $(0.0262)$ \\
& 1.107 \\
Unemployment & $(2.489)$ \\
& -0.570 \\
Secondary enrolment & $(0.401)$ \\
& 0.594 \\
Urbanization & $(0.407)$ \\
& -0.0791 \\
Openness & $(0.132)$ \\
& $\mathbf{0 . 2 2 6 *}$ \\
Provisioning & $\mathbf{( 0 . 1 1 8 )}$ \\
& 221 \\
& 33 \\
Observations & \\
Number of code & 0.183 \\
\hline Arellano-Bond Test & 0.333 \\
Order 1 p-value & \\
Order 2 p-value & \multicolumn{1}{c}{ Stald enc }
\end{tabular}

Standard errors in parentheses *** $\mathrm{p}<0.01,{ }^{* *} \mathrm{p}<0.05,{ }^{*} \mathrm{p}<0.1$ 
We then highlight the results of borrowers alone versus depositors alone to understand how macroprudential policies affect both of them. Table (3) outlines the results of our GMM regressions with borrowers as our dependent variable. Three interesting results emerge. First, tightening RRRs (Column (1)) increases borrowers at commercial banks by 5 individuals (per 1000 adults). This result is in line with Pearlman (2015) and Pearlman and Mirza (2017) who shows that there is a distributional effect of RRRs, with gains to borrowers when the RRR is tightened, as more potential borrowers are effectively able to borrow. Column (2) and (3) show that imposing countercyclical reserve requirements, ${ }^{60}$ and financial-institution-targeted ${ }^{61}$ instruments $^{62}$ increases financial inclusion by 42.3 and 10.8 individuals (per 1000 adults) respectively. With the addition of macroprudential tools, other explanatory variables lose significance. ${ }^{63}$

Table (4) displays additional macroprudential policies having an impact on borrowing. Most specifically, imposing taxes on financial institutions reduces borrowers by around 44 individuals (per 1000 adults) as can be shown in Column (1). This is an expected results as higher taxes on financial institutions could be translated into higher surcharges on the commercial banks' clients if banks seek to maintain their profitability. This, in turn, reduces the number of borrowers from commercial banks. Columns (2) and (3), however, show that provisions and limits on domestic currency loans - which aims to limit credit growth - increases the number of borrowers. Once again, this could be interpreted as a rise in the number of borrowers, but borrowers obtain smaller amounts, which increases access (and usage) of financial services (Pearlman 2015 and 2017).

\footnotetext{
${ }^{60}$ Another RRR measure from an alternative data, which captures restrictions to RRRs either by i) imposing a wedge on foreign currency deposits or ii) operates countercyclically.

${ }^{61}$ Instruments focused on financial institutions, rather than those targeting borrowers - as shown in Column 7 - and includes dynamic provisionings, countercyclical reserve requirements, limits on systemically important financial institutions. It is an aggregate instrument that captures the measures that target financial institutions. Annex I contains the full breakdown of the variables constituting this measure.

${ }^{62}$ Rather that instruments targeting borrowers.

${ }^{63}$ With urbanization and secondary enrolment showing some significance in additional tables as shown in Annex V.
} 
Table (3): Usage of Financial Services \& Macroprudential Policy Dependent variable: Borrowers from the Banking Sector: Borrowers from commercial banks per 1,000 adults Estimation Method: Arellano-Bover/Blundell-Bond Dynamic Panel System GMM.

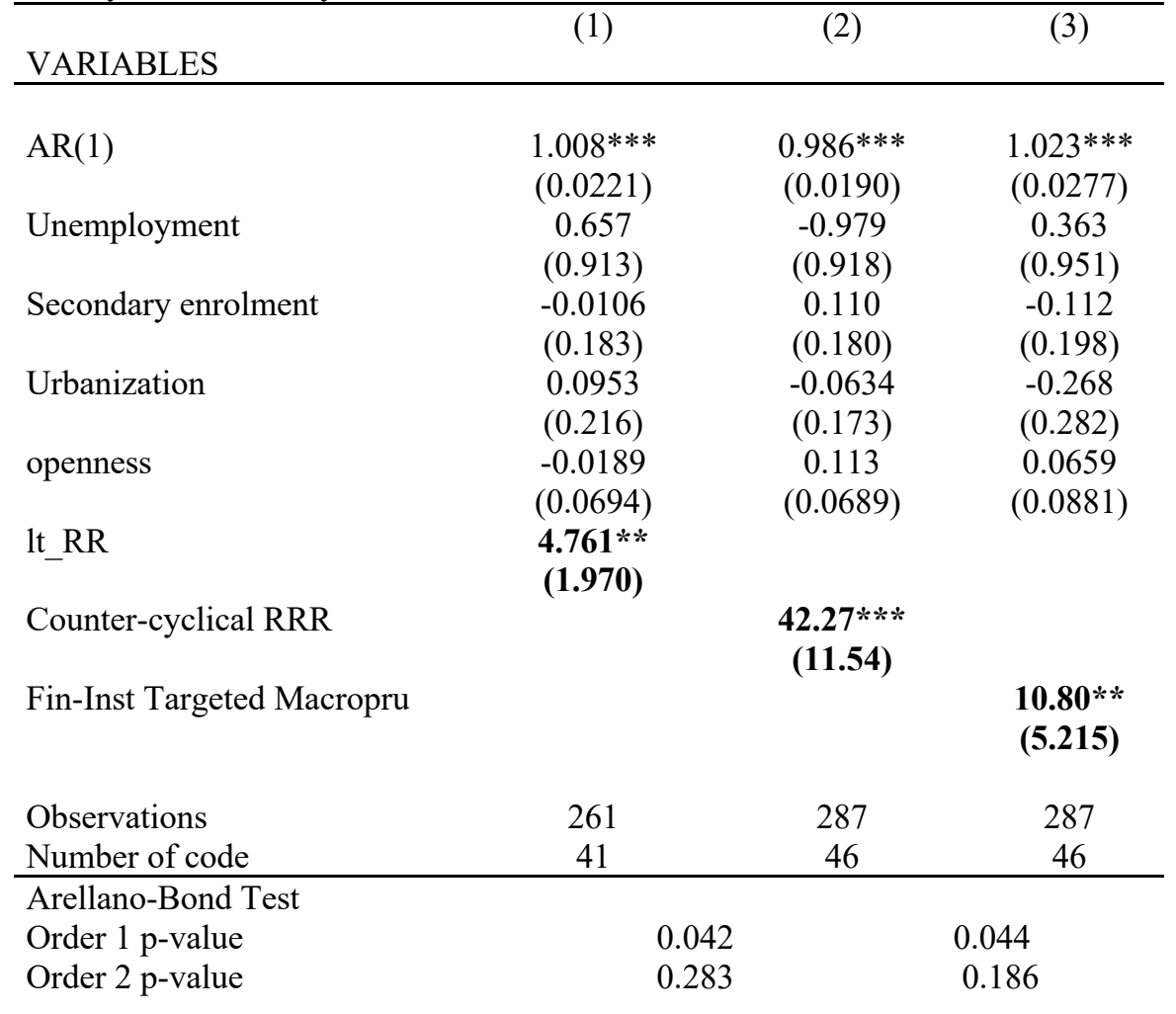

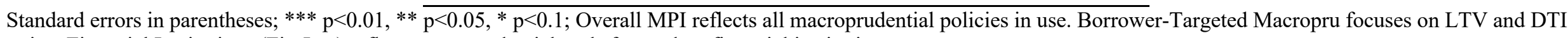
ratios; Financial Institutions (Fin-Inst) reflect macroprudential tools focused on financial institutions. 
Table (4): Usage of Financial Services \& Macroprudential Policy

Dependent variable: Borrowers from the Banking Sector: Borrowers from commercial banks per 1,000 adults

Estimation Method: Arellano-Bover/Blundell-Bond Dynamic Panel System GMM.

VARIABLES

$\mathrm{AR}(1)$
unemployment

Secondary enrolment

Urbanization

Openness

Tax

Domestic Loans Limits

Provisioning

$1.032 * * *$

(0.0339)

$-0.579$

(1.135)

0.0263

(0.197)

0.244

(0.219)

$-0.0298$

$(0.0697)$

$-43.46 * *$

(18.47)

Observations

Number of code

Arellano-Bond Test

Order 1 p-value

Order 2 p-value
(1)

(2)

(3)

$.050 * * *$

$1.023 * *$

$(0.0299) \quad(0.0208)$

$-0.128 \quad 1.874 * *$

$(0.857) \quad(0.730)$

0.230

$0.316^{* *}$

(0.206) $\quad(0.137)$

$-0.263 \quad 0.0770$

$(0.237) \quad(0.150)$

$-0.109 \quad 0.0163$

(0.0729) (0.0701)

25.06*

(13.61)

$0.140 * *$

(0.0665)

303

$287 \quad 287$

46

46

0.045

0.034

0.034

0.235

0.270

Standard errors in parentheses
$* * * \mathrm{p}<0.01, * * \mathrm{p}<0.05, * \mathrm{p}<0.1$ 


\subsection{Role of Governance}

We will now present our results when we interact governance with macroprudential policies, to determine the impact of regulatory/institutional quality on the effectiveness of macroprudential policies. We already highlighted that several studies, including Beck et al. (2007b) and Honohan (2008) found that institutional quality increases financial inclusion. Table (5) summarizes our results when we include financial development and institutional quality/governance indicators interacted with the various macroprudential tools for our full sample. ${ }^{64}$ Institutional quality appears to increase both usage and access to financial services across the spectrum of the macroprudential tools employed, with no negative impact on access. Financial development, on the other hand, appears to have mixed effects on our results, depending on the tool employed, and with no negative impact on usage. This sheds light on the importance of institutional quality both from a regulatory and an inclusion perspective, in terms of affecting the behavior of macroprudential policies, in terms of how they affect financial inclusion. Financial development, on the other hand, yields mostly mixed results in our regressions.

Table (5): Results with the Introduction of Governance and Financial Inclusion

\begin{tabular}{|c|c|c|c|c|}
\hline & \multicolumn{2}{|c|}{ Access } & \multicolumn{2}{|c|}{ Usage (borrowers and Depositors) } \\
\hline & Positive Impact & Negative Impact & Positive Impact & Negative Impact \\
\hline \multirow{6}{*}{ 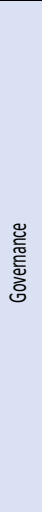 } & Provisionings & & $\begin{array}{c}\text { General Countercyclical Capital } \\
\text { Buffer/Requirement }\end{array}$ & $\begin{array}{c}\text { Taxes (adversely affects } \\
\text { borrowers) }\end{array}$ \\
\hline & $\begin{array}{c}\text { Macroprudential Index } \\
\text { (Overall Measure) }\end{array}$ & & Limits on Domestic Currency Loans & $\begin{array}{l}\text { Magnitude (rate of } \\
\text { change) of reserve } \\
\text { requirements }\end{array}$ \\
\hline & $\begin{array}{c}\text { FX and/or } \\
\text { Countercyclical } \\
\text { Reserve Requirements }\end{array}$ & & $\begin{array}{l}\text { Tighter Required Reserves/Usage of } \\
\text { Required Reserves Ratios }\end{array}$ & \\
\hline & $\begin{array}{c}\text { General } \\
\text { Countercyclical Capital } \\
\text { Buffer/Requirement }\end{array}$ & & $\begin{array}{l}\text { FX and/or Countercyclical Reserve } \\
\text { Requirements }\end{array}$ & \\
\hline & & & $\begin{array}{l}\text { Financial Institution Targeted } \\
\text { Instruments }\end{array}$ & \\
\hline & & & Provisionings & \\
\hline \multirow{5}{*}{ 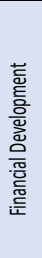 } & Tax & required reserve ratio & Borrower Targeted Instruments & \\
\hline & Provisionings & LTV ratio & $\begin{array}{c}\text { Financial Institution Targeted } \\
\text { Instruments }\end{array}$ & \\
\hline & $\begin{array}{c}\text { FX and/or } \\
\text { Countercyclical } \\
\text { Reserve Requirements }\end{array}$ & $\begin{array}{l}\text { Limits on Interbank } \\
\text { Exposures }\end{array}$ & LTV Caps & \\
\hline & & Risk Weights & Debt to Income Ratio & \\
\hline & & & Required Reserves, Levies, & \\
\hline
\end{tabular}

Table (6) presents our baseline model as before, which includes the various macroprudential policies, followed by their interaction with the governance indicators. As

\footnotetext{
${ }^{64}$ We do not split the sample in these regressions, as by definition, AEs have better institutional quality, and higher levels of financial development.
} 
can be seen in columns 1-4, all the interaction terms between the overall macroprudential index (MPI) in Column (1), ${ }^{65}$ provisioning in Column (2) and (4), and in counter cyclical reserve requirements in Column (3) are positive and significant. The total effect of macroprudential policies (presented in the last row), to signify the effect of macroprudential policies in the presence of improved institutional quality, also shows a statistically significant result, highlighting that as institutional quality improves, macroprudential policies increase financial inclusion. For example, Column (1) shows that increased use of macroprudential policies (proxied by Cerutti et al.'s (2015) overall macroprudential index in the presence of increased governance increases financial inclusion by $8 \%$ (relative to their insignificant impact on their own).

Table (6): Access to Financial Services \& Macroprudential Policy: Role of Governance

Dependent variable: Financial Access Variable (PCA of ATMs, Branches, and Accounts) in Columns (1); (2), and Financial Institutions and Markets Access (PCA of access to both institutions and markets), broader definition of access in Columns (3);(4).

Estimation Method: Arellano-Bover/Blundell-Bond Dynamic Panel System GMM.

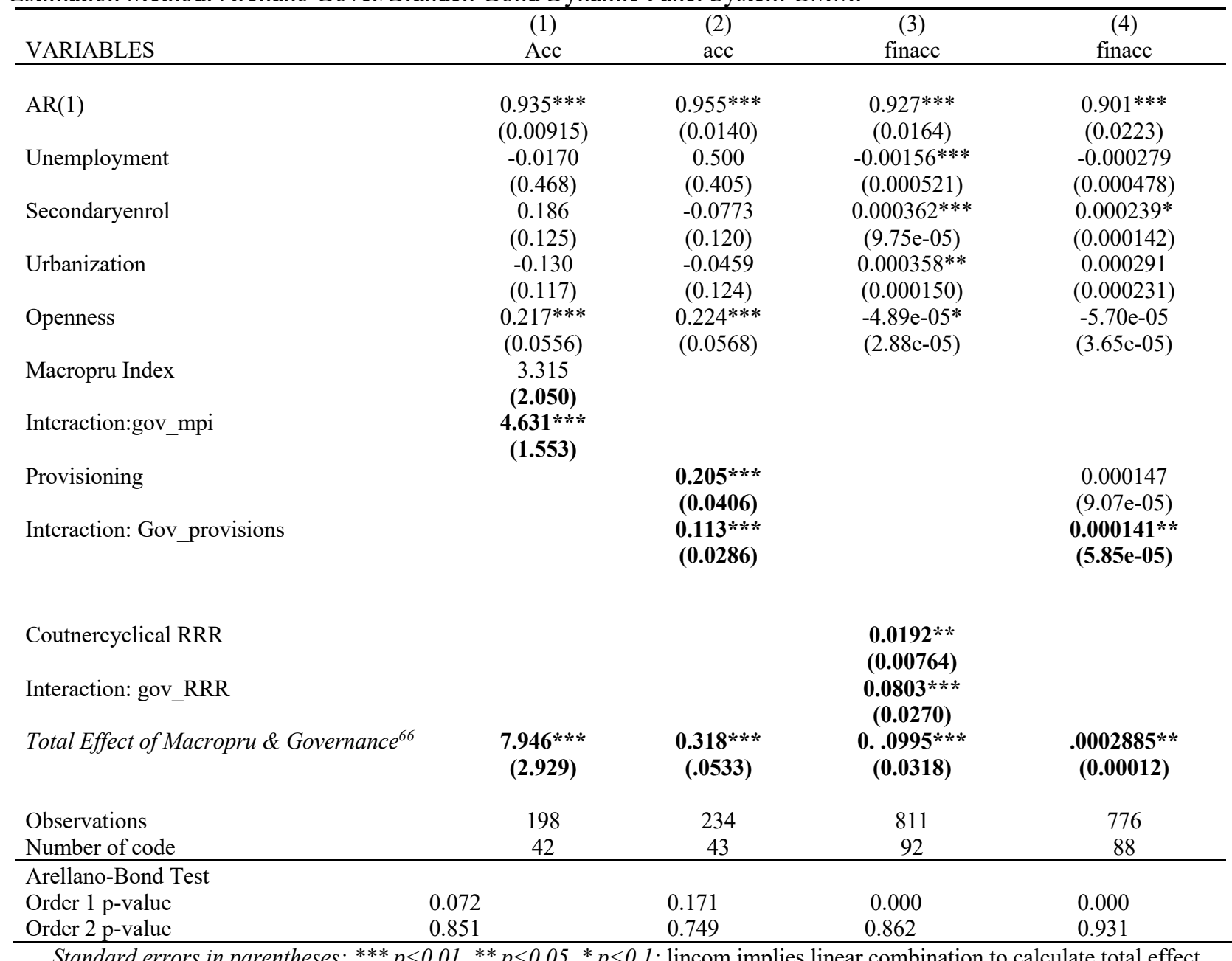

Table (7) presents the results of the usage of macroprudential policies, combining both borrowers

\footnotetext{
${ }^{65}$ Represents all macroprudential policies employed per country.

${ }^{66}$ That is, the effect of macroprudential policies conditional on governance/institutional quality.
} 
and users using principal component analysis. In this case, only the general countercyclical capital buffer/requirement yielded a positive and significant result on usage of financial services,${ }^{67}$ whereby the (total) effect of macroprudential policies almost doubles as institutional quality improves.

Table (7): Usage of Financial Services \& Macroprudential Policy

Dependent variable: Depositors and Borrowers from the Banking Sector (Principal Component Analysis of Both) Estimation Method: Arellano-Bover/Blundell-Bond Dynamic Panel System GMM.

(1)

\begin{tabular}{lc} 
VARIABLES & $(1)$ \\
\hline & $1.007 * * *$ \\
AR(1) & $(0.0290)$ \\
& 0.584 \\
unemployment & $(3.012)$ \\
& -0.478 \\
secondaryenrol & $(0.542)$ \\
& $0.879^{* *}$ \\
urbanization & $(0.394)$ \\
& 0.00342 \\
openness & $(0.169)$ \\
& $\mathbf{9 3 . 2 9 * *}$ \\
Countercyclical Capital & $(\mathbf{3 8 . 7 1 )}$ \\
Buffer/Requirement (CTC) & $118.8^{* * *}$ \\
& $(42.38)$ \\
Interaction: gov_CTC & $\mathbf{2 1 2 . 1 3 * * *}$ \\
& $\mathbf{( 7 2 . 9 6 )}$ \\
Effect of Macroprudential & \\
Policies under findev & \\
(lincom) & 204 \\
Observations & 36 \\
Number of code & 0.154 \\
\hline Arellano-Bond Test & 0.205 \\
Order 1 p-value & \\
Order 2 p-value & \\
\hline
\end{tabular}

Standard errors in parentheses

$* * * \mathrm{p}<0.01, * * \mathrm{p}<0.05, * \mathrm{p}<0.1 ;$ lincom implies linear combination to calculate total effect

Table (8) presents our results using borrowers as the dependent variable. We observe that the same variables as before displayed positive statistical significance, in addition to limits on domestic loans (CG: Column (3)). The interaction terms have been significant except for taxes, provisioning, and the financial-targeted instruments. ${ }^{68}$ However, the total effect of macroprudential policies ${ }^{69}$ was significant in increasing financial inclusion, across all variables in Table (11), except for Columns (4) and (5), for provisioning and RRRs. Column (6) includes another measure of RRR tightening based on our own data collection relative to Column (5) from Shim et al.'s (2013) database, and our variable was positive and significant when interacted with institutional quality, confirming earlier findings.

\footnotetext{
${ }^{67}$ Otherwise, results were insignificant.

${ }^{68}$ Note the mixed effect of the RRR in this table, versus its significance in the baseline regression.

${ }^{69}$ Conditional on improved institutional quality.
} 
Table (8): Usage of Financial Services \& Macroprudential Policy

Dependent variable: Borrowers from Commercial Banks (per 1000 adults)

Estimation Method: Arellano-Bover/Blundell-Bond Dynamic Panel System GMM

\begin{tabular}{|c|c|c|c|c|c|c|c|c|}
\hline VARIABLES & (1) & (2) & (3) & (4) & (5) & (6) & (7) & $(8)$ \\
\hline $\operatorname{AR}(1)$ & $\begin{array}{l}1.035^{* * *} \\
(0.0199)\end{array}$ & $\begin{array}{l}1.026^{* * *} * \\
(0.0334)\end{array}$ & $\begin{array}{l}1.044 * * * \\
(0.0333)\end{array}$ & $\begin{array}{l}1.020 * * * \\
(0.0220)\end{array}$ & $\begin{array}{l}1.016^{* * *} \\
(0.0298)\end{array}$ & $\begin{array}{c}0.978 * * * \\
(0.0228)\end{array}$ & $\begin{array}{c}0.958 * * * \\
(0.0195)\end{array}$ & $\begin{array}{l}1.006^{* * *} * \\
(0.0227)\end{array}$ \\
\hline unemp & $\begin{array}{c}0.102 \\
(1.381)\end{array}$ & $\begin{array}{l}-0.480 \\
(1.223)\end{array}$ & $\begin{array}{l}-0.221 \\
(0.934)\end{array}$ & $\begin{array}{l}1.812 * * \\
(0.688)\end{array}$ & $\begin{array}{c}0.604 \\
(0.969)\end{array}$ & $\begin{array}{l}0.667 \\
(0.861)\end{array}$ & $\begin{array}{l}-1.009 \\
(0.924)\end{array}$ & $\begin{array}{c}0.540 \\
(1.096)\end{array}$ \\
\hline secondaryenrol & $\begin{array}{l}-0.0341 \\
(0.205)\end{array}$ & $\begin{array}{l}0.0315 \\
(0.202)\end{array}$ & $\begin{array}{l}0.475^{* *} \\
(0.221)\end{array}$ & $\begin{array}{c}-0.313^{* *} \\
(0.138)\end{array}$ & $\begin{array}{l}0.0148 \\
(0.212)\end{array}$ & $\begin{array}{l}0.0312 \\
(0.180)\end{array}$ & $\begin{array}{l}0.163 \\
(0.176)\end{array}$ & $\begin{array}{r}-0.0541 \\
(0.221)\end{array}$ \\
\hline urb & $\begin{array}{l}0.0676 \\
(0.143)\end{array}$ & $\begin{array}{c}0.259 \\
(0.229)\end{array}$ & $\begin{array}{l}-0.457^{*} \\
(0.243)\end{array}$ & $\begin{array}{l}0.0833 \\
(0.149)\end{array}$ & $\begin{array}{l}0.0461 \\
(0.267)\end{array}$ & $\begin{array}{l}0.197 \\
(0.166)\end{array}$ & $\begin{array}{l}0.0662 \\
(0.244)\end{array}$ & $\begin{array}{l}-0.311 \\
(0.272)\end{array}$ \\
\hline openness & $\begin{array}{l}-0.0195 \\
(0.0611)\end{array}$ & $\begin{array}{l}-0.0391 \\
(0.0688)\end{array}$ & $\begin{array}{l}-0.217 * * \\
(0.0877)\end{array}$ & $\begin{array}{c}0.0180 \\
(0.0724)\end{array}$ & $\begin{array}{l}-0.0295 \\
(0.0757)\end{array}$ & $\begin{array}{l}-0.0653 \\
(0.0780)\end{array}$ & $\begin{array}{c}0.0690 \\
(0.0842)\end{array}$ & $\begin{array}{c}0.0527 \\
(0.0944)\end{array}$ \\
\hline $\begin{array}{l}\text { Countercyclical Capital } \\
\text { Buffe (CTC) }\end{array}$ & 40.56 & & & & & & & \\
\hline Interaction: gov_ctc & $\begin{array}{l}(28.43) \\
\text { 30.88* } \\
(\mathbf{1 7 . 5 2})\end{array}$ & & & & & & & \\
\hline Taxes & & $\begin{array}{c}-46.09 * * \\
(20.68)\end{array}$ & & & & & & \\
\hline Interaction: gov_tax & & $\begin{array}{c}8.712 \\
(23.02)\end{array}$ & & & & & & \\
\hline $\begin{array}{l}\text { Domestic Loans Limit } \\
\text { (cg) }\end{array}$ & & & $\begin{array}{l}47.14 * * \\
(18.15)\end{array}$ & & & & & \\
\hline Interaction: gov_cg & & & $\begin{array}{l}48.44^{*} \\
(27.67)\end{array}$ & & & & & \\
\hline provisioning & & & & $\begin{array}{l}0.138 * * \\
(0.0685)\end{array}$ & & & & \\
\hline $\begin{array}{l}\text { Interaction: } \\
\text { gov_provisioning }\end{array}$ & & & & $\begin{array}{l}-0.0296 \\
(0.0471)\end{array}$ & & & & \\
\hline lt_RR & & & & & $\begin{array}{c}4.760 * * \\
(2.310)\end{array}$ & & & \\
\hline Interaction: gov_lt_rr & & & & & $\begin{array}{l}4.765 \\
(5.258)\end{array}$ & & & \\
\hline 1t_rr2 & & & & & & $\begin{array}{c}6.762 \\
(4.147)\end{array}$ & & \\
\hline Interaction: gov_lt_rr2 & & & & & & $\begin{array}{l}12.35 * * \\
(5.423)\end{array}$ & & \\
\hline
\end{tabular}




\begin{tabular}{|c|c|c|c|c|c|c|c|c|}
\hline VARIABLES & (1) & $(2)$ & (3) & (4) & (5) & (6) & (7) & (8) \\
\hline Fin-Target Macropru & & & & & & & & $12.55 * *$ \\
\hline Interaction: gov_fintgt & & & & & & & & $\begin{array}{l}5.548 \\
(4.840)\end{array}$ \\
\hline $\begin{array}{l}\text { Effect of } \\
\text { Macroprudential }\end{array}$ & $\begin{array}{c}\text { 71.44* } \\
(43.446)\end{array}$ & $\begin{array}{l}-37.37 * \\
(22.754)\end{array}$ & $\begin{array}{l}95.58 * * \\
(43.398)\end{array}$ & $\begin{array}{c}0.109 \\
(0.0977)\end{array}$ & $\begin{array}{c}9.524 \\
(6.997)\end{array}$ & $\begin{array}{l}19.12 * * \\
(8.195)\end{array}$ & $\begin{array}{c}142 * * * \\
(2.83)\end{array}$ & $\begin{array}{c}18.102 * * \\
(9.794)\end{array}$ \\
\hline $\begin{array}{l}\text { Policies under findev } \\
\text { (lincom) }\end{array}$ & & & & & & & & \\
\hline Observations & 287 & 287 & 287 & 303 & 261 & 339 & 287 & 287 \\
\hline Number of code & 46 & 46 & 46 & 44 & 41 & 47 & 46 & 46 \\
\hline Arellano-Bond Test & & & & & & & & \\
\hline Order 1 p-value & 0.046 & 0.041 & 0.048 & 0.034 & 0.028 & 0.021 & 0.041 & 0.045 \\
\hline Order 2 p-value & 0.183 & 0.275 & 0.306 & 0.270 & 0.288 & 0.455 & 0.333 & 0.212 \\
\hline
\end{tabular}


Table (9) presents alternative usage measure capturing depositors, and with the exception of Column (5), which represents the magnitude of tightening (or the rate of change of the reserve requirements), macroprudential policies appear to have a positive and significant impact on depositors. Interestingly, two other measures capturing the RRRs show their positive impact; variables capturing their countercyclicality (Column (3)) and tightening and loosening (Column (1)). The last row represents the total effect, and confirms this pattern for most regressions, showing that the impact of macroprudential policies in the presence of governance increases the number of depositors. Overall results point towards the fact that institutional quality matters for the effectiveness of the macroprudential policies employed, and that improved governance increases financial inclusion as a result of the implementation of macroprudential policies. Overall, our results point towards the importance of governance - as a proxy for institutional and regulatory quality - in affecting the behavior of macroprudential policies, whereby the usage of macroprudential policies improves financial regulation in the presence of better governance. 
Table (9): Usage of Financial Services \& Macroprudential Policy

Dependent variable: Depositors in Commercial Banks (per 1000 adults)

Estimation Method: Arellano-Bover/Blundell-Bond Dynamic Panel System GMM.

\begin{tabular}{|c|c|c|c|c|c|c|c|}
\hline VARIABLES & $(1)$ & (2) & (3) & (4) & (5) & (6) & (7) \\
\hline $\operatorname{AR}(1)$ & $\begin{array}{c}0.968^{* * *} \\
(0.0148)\end{array}$ & $\begin{array}{c}0.984 * * * \\
(0.0114)\end{array}$ & $\begin{array}{c}0.969 * * * \\
(0.0320)\end{array}$ & $\begin{array}{c}0.958 * * * \\
(0.0272)\end{array}$ & $\begin{array}{c}0.960 * * * \\
(0.0190)\end{array}$ & $\begin{array}{c}0.997 * * * \\
(0.0149)\end{array}$ & $\begin{array}{l}\text { J.983*** } \\
(0.0343)\end{array}$ \\
\hline Unemployment & $\begin{array}{c}0.402 \\
(1.265)\end{array}$ & $\begin{array}{c}2.006 \\
(1.937)\end{array}$ & $\begin{array}{l}-1.635 \\
(3.512)\end{array}$ & $\begin{array}{l}-1.494 \\
(1.231)\end{array}$ & $\begin{array}{l}-0.833 \\
(1.848)\end{array}$ & $\begin{array}{l}-1.071 \\
(1.307)\end{array}$ & $\begin{array}{c}0.855 \\
(3.449)\end{array}$ \\
\hline Secondaryenrolment & $\begin{array}{c}-0.921^{* *} \\
(0.439)\end{array}$ & $\begin{array}{c}-1.740 * * * \\
(0.589)\end{array}$ & $\begin{array}{c}-0.340 \\
(0.647)\end{array}$ & $\begin{array}{c}-1.588 * * \\
(0.752)\end{array}$ & $\begin{array}{c}-0.577 \\
(0.460)\end{array}$ & $\begin{array}{c}-0.756^{* *} \\
(0.352)\end{array}$ & $\begin{array}{c}-1.049 \\
(0.672)\end{array}$ \\
\hline Urbanization & $\begin{array}{c}2.319^{* * *} \\
(0.559)\end{array}$ & $\begin{array}{c}2.939 * * * \\
(0.710)\end{array}$ & $\begin{array}{c}1.372 \\
(1.049)\end{array}$ & $\begin{array}{l}1.925^{* *} \\
(0.728)\end{array}$ & $\begin{array}{c}2.184 * * * \\
(0.673)\end{array}$ & $\begin{array}{c}0.941 \\
(0.638)\end{array}$ & $\begin{array}{c}0.399 \\
(0.904)\end{array}$ \\
\hline Openness & $\begin{array}{c}0.263 * * \\
(0.103)\end{array}$ & $\begin{array}{c}0.186 \\
(0.149)\end{array}$ & $\begin{array}{c}0.434 * * * \\
(0.160)\end{array}$ & $\begin{array}{c}-0.0440 \\
(0.291)\end{array}$ & $\begin{array}{c}0.205 \\
(0.176)\end{array}$ & $\begin{array}{c}0.240 * * \\
(0.118)\end{array}$ & $\begin{array}{c}0.629 * * \\
(0.293)\end{array}$ \\
\hline lt_RRR & $\begin{array}{c}3.457 \\
(8.796)\end{array}$ & & & & & & \\
\hline Interaction: gov_lt_RRR & $\begin{array}{c}21.26 * * \\
(10.55)\end{array}$ & & & & & & \\
\hline lt_Risk Weights & & $\begin{array}{l}109.0^{*} \\
(62.24)\end{array}$ & & & & & \\
\hline Interaction: gov_lt_Risk Weights & & $\begin{array}{l}-68.72 \\
(76.25)\end{array}$ & & & & & \\
\hline Countercyclial Capital Buffer & & & $\begin{array}{c}111.1 * * * \\
(40.54)\end{array}$ & & & & \\
\hline Interaction: Gov_Capital Buffer & & & $\begin{array}{c}185.9 \\
(152.4)\end{array}$ & & & & \\
\hline RRR & & & & $\begin{array}{c}152.1 * \\
(79.45)\end{array}$ & & & \\
\hline Interaction gov_rr & & & & $\begin{array}{c}11.35 \\
(30.65)\end{array}$ & & & \\
\hline RRR (change) & & & & & $\begin{array}{c}-8.819 \\
(5.915)\end{array}$ & & \\
\hline Interaction: gov_rrr chane & & & & & $\begin{array}{c}-17.20 * \\
(9.319)\end{array}$ & & \\
\hline provisioning & & & & & & $\begin{array}{c}0.396 * * \\
(0.198)\end{array}$ & \\
\hline Interaction: gov_provisioning & & & & & & $\begin{array}{c}0.0382 \\
(0.191)\end{array}$ & \\
\hline Concentration limits & & & & & & & $\begin{array}{l}115.2^{* *} \\
(51.89)\end{array}$ \\
\hline Interactions: gov_concentration limit & & & & & & & $\begin{array}{c}2.644 \\
(51.64)\end{array}$ \\
\hline Total Effect of Macroprudential Policies & 24.72 & 40.27 & $297.02 *$ & $163.41 *$ & $-26.021 *$ & $0.4347^{*}$ & 117.834 \\
\hline
\end{tabular}




\begin{tabular}{|c|c|c|c|c|c|c|c|}
\hline under findev (lincom) & $(16.375)$ & $(46.654)$ & $(159.12)$ & (96.08) & (15.074) & $(0.2444)$ & $(87.665)$ \\
\hline $\begin{array}{l}\text { Observations } \\
\text { Number of code }\end{array}$ & $\begin{array}{c}369 \\
55\end{array}$ & $\begin{array}{c}259 \\
37\end{array}$ & $\begin{array}{c}427 \\
64\end{array}$ & $\begin{array}{c}519 \\
67\end{array}$ & $\begin{array}{c}483 \\
64\end{array}$ & $\begin{array}{c}452 \\
58\end{array}$ & $\begin{array}{r}427 \\
64\end{array}$ \\
\hline \multicolumn{8}{|l|}{ Arellano-Bond Test } \\
\hline Order $1 \mathrm{p}$-value & 0.018 & 0.030 & 0.056 & 0.038 & 0.031 & 0.049 & 0.056 \\
\hline Order 2 p-value & 0.737 & 0.666 & 0.758 & 0.990 & 0.846 & 0.676 & 0.714 \\
\hline
\end{tabular}

$* * * \mathrm{p}<0.01, * * \mathrm{p}<0.05, * \mathrm{p}<0.1$; lincom implies linear combination to calculate total effect 


\subsection{Role of Financial Development}

Table (10) highlights results when we include a proxy for financial development- capturing the depth and efficiency of a country's financial sector- and interacting this variable (findev) with our macroprudential indicators. ${ }^{70}$ In these regressions, we have mixed results on the impact and effectiveness of macroprudential policies. Column (1) indicates that the interaction of the RRR with financial development lowers access to finance, while the RRR on its own has no impact, a result that contrasts previous findings in our baseline regressions, and upon the introduction of governance indicators. The total effect (the last row) confirms the negative impact of the RRR as a result of increased financial development. Similar results are obtained using the LTV ratio (Column 5), but this is an expected result. Limits on the fraction of liabilities held by the banking sector or by an individual in Column (3) also yielded a negative impact on financial access. Only taxes appear to have a positive impact on access in Column (2).

Table (10): Financial Inclusion \& Macroprudential Policy Dependent variable: Financial Access Variable (PCA of ATMs, Branches, and Accounts) Estimation Method: Arellano-Bover/Blundell-Bond Dynamic Panel System GMM.

\begin{tabular}{|c|c|c|c|c|c|}
\hline VARIABLES & (1) & (2) & (3) & (4) & (5) \\
\hline $\operatorname{AR}(1)$ & $\begin{array}{c}1.028 * * * \\
(0.0138)\end{array}$ & $\begin{array}{c}0.932 * * * \\
(0.0137)\end{array}$ & $\begin{array}{c}0.944 * * * \\
(0.0383)\end{array}$ & $\begin{array}{l}1.000 * * * \\
(0.0177)\end{array}$ & $\begin{array}{l}1.021 * * * \\
(0.0152)\end{array}$ \\
\hline Unemployment & $\begin{array}{c}0.253 \\
(0.663)\end{array}$ & $\begin{array}{c}-1.176 \\
(0.899)\end{array}$ & $\begin{array}{c}-1.178 \\
(0.891)\end{array}$ & $\begin{array}{c}0.471 \\
(0.495)\end{array}$ & $\begin{array}{l}-3.024 * \\
(1.642)\end{array}$ \\
\hline Secondaryenrolment & $\begin{array}{c}0.0433 \\
(0.165)\end{array}$ & $\begin{array}{l}0.367 * \\
(0.201)\end{array}$ & $\begin{array}{c}0.275 \\
(0.225)\end{array}$ & $\begin{array}{c}-0.0386 \\
(0.113)\end{array}$ & $\begin{array}{l}0.0236 \\
(0.220)\end{array}$ \\
\hline urbanization & $\begin{array}{c}-0.0574 \\
(0.175)\end{array}$ & $\begin{array}{c}-0.0210 \\
(0.222)\end{array}$ & $\begin{array}{r}-0.0947 \\
(0.171)\end{array}$ & $\begin{array}{c}0.0468 \\
(0.132)\end{array}$ & $\begin{array}{l}0.385 * \\
(0.197)\end{array}$ \\
\hline Openness & $\begin{array}{c}0.0294 \\
(0.0596)\end{array}$ & $\begin{array}{c}0.198 * * * \\
(0.0700)\end{array}$ & $\begin{array}{l}0.196 * * \\
(0.0776)\end{array}$ & $\begin{array}{l}0.120 * * \\
(0.0486)\end{array}$ & $\begin{array}{l}-0.0142 \\
(0.0441)\end{array}$ \\
\hline lt_RRR & $\begin{array}{c}8.207 \\
(5.463)\end{array}$ & & & & \\
\hline Interaction: findevv_lt_rr & $\begin{array}{c}-140.3 * * \\
(66.06)\end{array}$ & & & & \\
\hline Tax & & $\begin{array}{l}-60.42 \\
(37.86)\end{array}$ & & & \\
\hline Interaction: findevv_tax & & $\begin{array}{l}369.4 * \\
(198.0)\end{array}$ & & & \\
\hline Inter-bank exposure & & & $\begin{array}{c}27.11 \\
(16.41)\end{array}$ & & \\
\hline $\begin{array}{l}\text { Interaction: findevv_interbank } \\
\text { expsure }\end{array}$ & & & $-94.63 *$ & & \\
\hline
\end{tabular}

\footnotetext{
${ }^{70}$ We are mainly interested in the role of financial development interacted with macroprudential policies, so we do not report the coefficients of the financial development variables. Nor do we include them in our regressions. Econometrically, researchers either include one or both variables within an interaction term depending on the research question examined.
} 
RRR change ${ }^{71}$

Interaction: findevv_drr_act

It_ltv

findevv_lt_ltv

Effect of Macroprudential

Policies under findev (lincom)

Observations

Number of code

Arellano-Bond Test

Order $1 \mathrm{p}$-value

Order 2 p-value
$-132.1306^{* *}$

(61.32)

172

36

0.046
0.786

0.053

0.617

$309.02 * *$
$(171.48)$

$-67.51$

(49.84)

$-8.94$

$1.311^{*}$

$(0.778)$

$-10.25$

(10.47)

14.03

(10.81)

$-65.96 * *$

(30.39)

$-51.92 * *$

(21.57)

$(9.75)$

85

$198 \quad 220$

44

Standard errors in parentheses
$* * * \mathrm{p}<0.01,{ }^{* *} \mathrm{p}<0.05,{ }^{*} \mathrm{p}<0.1$

Table (11) shows that that risk weights (Column (1)) also have a negative impact on inclusion when interacted with financial development, while provisioning and the (countercyclical) reserve requirement appear to have a positive impact. Risk weights generally make it costly for banks to extend loans (Shim et al., 2013) so this result is expected.

\footnotetext{
${ }^{71}$ Actual RRRs values not dummies
} 
Table (11): Financial Inclusion \& Macroprudential Policy

Dependent variable: Financial Access Variable (PCA of ATMs, Branches, and Accounts)

Estimation Method: Arellano-Bover/Blundell-Bond Dynamic Panel System GMM.

(1)

(2)

(3)

(4)

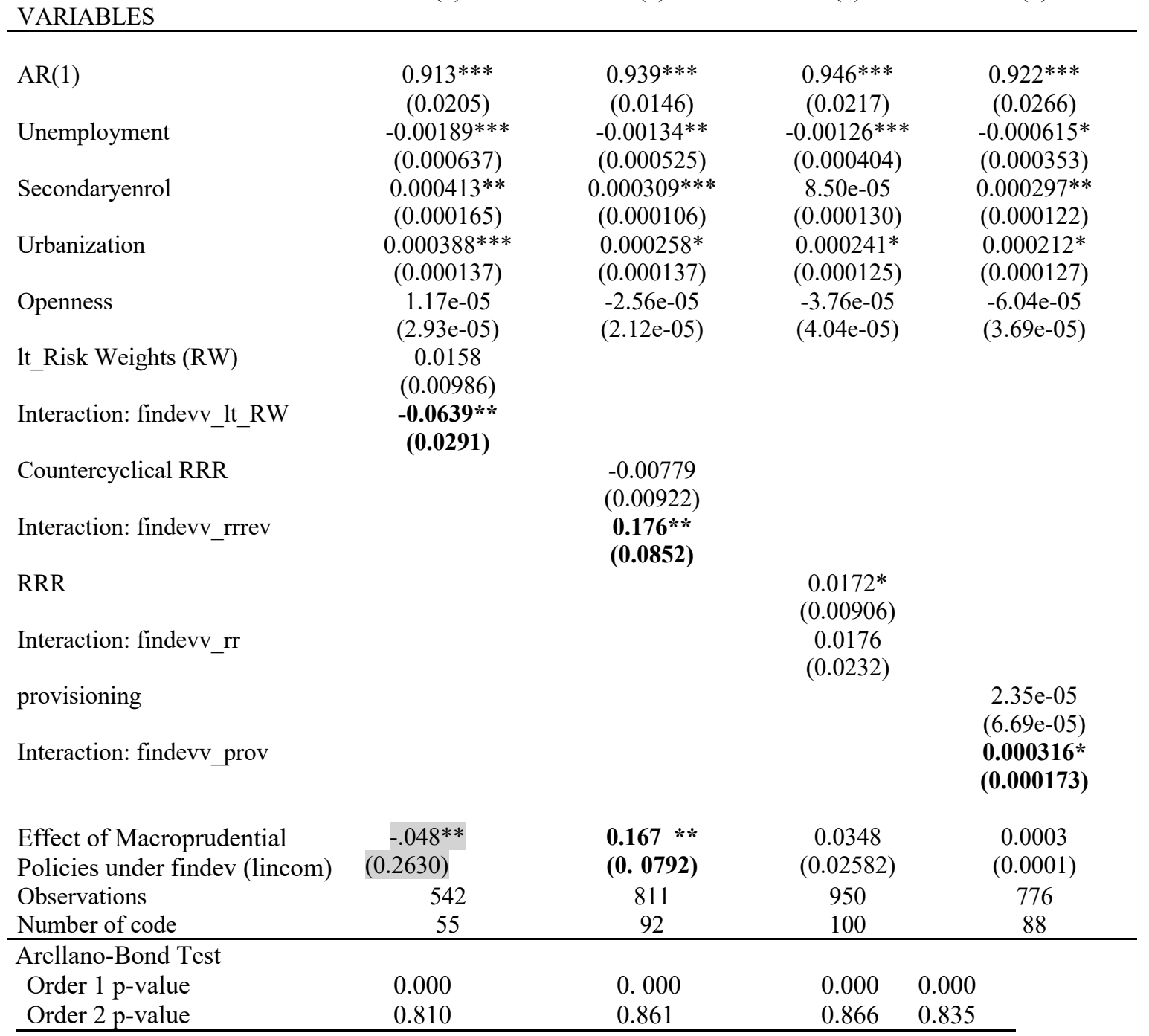

Standard errors in parentheses

$* * * \mathrm{p}<0.01, * * \mathrm{p}<0.05$ 
Table (12) shows the results of usage of financial services whereby both depositors and borrowers, comprise our dependent variable (using principal component analysis). Unlike access to financial services in Table (11), all the results within Table (12) showing that macroprudential policies, in the presence of financial development leads to a positive and significant impact on usage of financial services. Interestingly, the strongest results are those concerning the LTV and DTI ratio in Columns (5) and (6). Columns (5) and (6) show that tightening the LTV ratio and DTI ratios lowers usage- both depositing and borrowing- by $36 \%$ and $45 \%$ respectively. However, their interaction with financial development alters this result, whereby they both become positive and significant. Even more so, the total effect of tightening both LTV ratios and debt o income ratios continues to be positive and significant. All other tools in this table display a positive and statistically significant impact on usage of financial services.

Upon dividing usage from Table (12) into borrowers (Table 13), and depositors (Table 14) only two variables, required reserves and levies, appear to have a positive impact on usage in the presence of financial inclusion. What is important to observe here is that macroprudential policies do not appear to have a negative impact on usage of financial services when we account for financial development. 
Table (12): Financial Inclusion \& Macroprudential Policy

Dependent variable: Usage of Financial Services, borrowers and depositors in commercial banks (per 1000 adults).

Estimation Method: Arellano-Bover/Blundell-Bond Dynamic Panel System GMM.

\begin{tabular}{|c|c|c|c|c|c|c|c|}
\hline VARIABLES & $\begin{array}{c}(1) \\
\text { DepBor }\end{array}$ & $\begin{array}{c}(2) \\
\text { DepBor }\end{array}$ & $\begin{array}{c}(3) \\
\text { DepBor }\end{array}$ & $\begin{array}{c}(4) \\
\text { DepBor } \\
\end{array}$ & $\begin{array}{c}(5) \\
\text { DepBor }\end{array}$ & $\begin{array}{c}(6) \\
\text { DepBor }\end{array}$ & $\begin{array}{c}(7) \\
\text { DepBor }\end{array}$ \\
\hline $\operatorname{AR}(1)$ & $\begin{array}{c}0.996 * * * \\
(0.0178)\end{array}$ & $\begin{array}{l}0.998 * * * \\
(0.0223)\end{array}$ & $\begin{array}{l}0.990 * * * \\
(0.0208)\end{array}$ & $\begin{array}{l}1.005^{* * *} \\
(0.0174)\end{array}$ & $\begin{array}{l}1.003 * * * \\
(0.0186)\end{array}$ & $\begin{array}{l}0.984 * * * \\
(0.0168)\end{array}$ & $\begin{array}{l}1.013 * * * \\
(0.0191)\end{array}$ \\
\hline Unemployment & $\begin{array}{c}1.206 \\
(2.674)\end{array}$ & $\begin{array}{c}1.148 \\
(1.986)\end{array}$ & $\begin{array}{l}3.079 * \\
(1.646)\end{array}$ & $\begin{array}{c}0.286 \\
(1.473)\end{array}$ & $\begin{array}{l}0.0220 \\
(1.716)\end{array}$ & $\begin{array}{l}0.0812 \\
(2.476)\end{array}$ & $\begin{array}{l}-0.649 \\
(1.928)\end{array}$ \\
\hline Secondaryenrolment & $\begin{array}{l}-0.261 \\
(0.671)\end{array}$ & $\begin{array}{l}-0.651 \\
(0.548)\end{array}$ & $\begin{array}{c}-0.790^{* *} \\
(0.331)\end{array}$ & $\begin{array}{l}-0.0762 \\
(0.557)\end{array}$ & $\begin{array}{l}-0.307 \\
(0.486)\end{array}$ & $\begin{array}{l}-0.488 \\
(0.560)\end{array}$ & $\begin{array}{l}-0.463 \\
(0.425)\end{array}$ \\
\hline Urbanization & $\begin{array}{c}0.792 \\
(0.547)\end{array}$ & $\begin{array}{c}0.567 \\
(0.725)\end{array}$ & $\begin{array}{l}1.114^{* *} \\
(0.413)\end{array}$ & $\begin{array}{c}0.756 \\
(0.546)\end{array}$ & $\begin{array}{l}1.055^{* *} \\
(0.478)\end{array}$ & $\begin{array}{l}0.888^{*} \\
(0.472)\end{array}$ & $\begin{array}{l}1.026^{* *} \\
(0.398)\end{array}$ \\
\hline Openness & $\begin{array}{l}-0.254^{*} \\
(0.138)\end{array}$ & $\begin{array}{l}0.0413 \\
(0.161)\end{array}$ & $\begin{array}{c}-0.00422 \\
(0.129)\end{array}$ & $\begin{array}{c}-0.325^{* * * *} \\
(0.107)\end{array}$ & $\begin{array}{l}-0.217^{*} \\
(0.124)\end{array}$ & $\begin{array}{c}0.110 \\
(0.161)\end{array}$ & $\begin{array}{c}-0.0778 \\
(0.114)\end{array}$ \\
\hline Borrower-Targeted Macropru & $\begin{array}{c}-22.36^{* * * *} \\
(7.978)\end{array}$ & & & & & & \\
\hline Interaction: findevv_borrtrg & $\begin{array}{l}218.9 * * * \\
(56.63)\end{array}$ & & & & & & \\
\hline Financial_Inst Targeted Macropru & & $\begin{array}{c}3.844 \\
(7.785)\end{array}$ & & & & & \\
\hline Interaction: findevv_fintgt & & $\begin{array}{l}73.69 * \\
(40.41)\end{array}$ & & & & & \\
\hline rr_act & & & $\begin{array}{l}-0.562 \\
(0.622)\end{array}$ & & & & \\
\hline Interaction: findevv_rr_act & & & $\begin{array}{l}8.777 * \\
(4.952)\end{array}$ & & & & \\
\hline ltv_cap & & & & $\begin{array}{c}-39.19 * * \\
(16.52)\end{array}$ & & & \\
\hline Interaction: findevv_ltv_cap & & & & $\begin{array}{c}250.6 * * * \\
(75.76)\end{array}$ & & & \\
\hline Ltv & & & & & $\begin{array}{c}-36.30^{* *} \\
(16.20)\end{array}$ & & \\
\hline Interaction: findevv_ltv & & & & & $\begin{array}{l}173.3 * * \\
(69.34)\end{array}$ & & \\
\hline DTI & & & & & & $\begin{array}{c}-45.65 * * \\
(21.08)\end{array}$ & \\
\hline Interaction: findevv_dti & & & & & & $\begin{array}{c}595.4 * * * \\
(191.8)\end{array}$ & \\
\hline Countercyclical Capital Buffer & & & & & & & $\begin{array}{l}116.5 * * \\
(56.24)\end{array}$ \\
\hline $\begin{array}{l}\text { Interaction: findevv_countercyclial } \\
\text { capital buffer }\end{array}$ & & & & & & & $\begin{array}{l}-3,354 \\
(2,526)\end{array}$ \\
\hline $\begin{array}{l}\text { Effect of Macroprudential } \\
\text { Policies under findev (lincom) }\end{array}$ & $\begin{array}{l}196.56 * * * \\
(55.54)\end{array}$ & $\begin{array}{l}77.53 * * \\
(37.96)\end{array}$ & $\begin{array}{r}8.22 * \\
(4.719)\end{array}$ & $\begin{array}{c}211.37 * * * \\
(71.50)\end{array}$ & $\begin{array}{l}136.99 * * * \\
(66.67)\end{array}$ & $\begin{array}{c}549.76 * * * \\
(183.28)\end{array}$ & $\begin{array}{l}-3237.65 \\
(2475.45)\end{array}$ \\
\hline $\begin{array}{l}\text { Observations } \\
\text { Number of code }\end{array}$ & $\begin{array}{c}198 \\
35\end{array}$ & $\begin{array}{c}198 \\
35 \\
\end{array}$ & $\begin{array}{c}208 \\
35 \\
\end{array}$ & $\begin{array}{c}198 \\
35 \\
\end{array}$ & $\begin{array}{c}198 \\
35 \\
\end{array}$ & $\begin{array}{c}198 \\
35 \\
\end{array}$ & $\begin{array}{c}198 \\
35 \\
\end{array}$ \\
\hline $\begin{array}{l}\text { Arellano-Bond Test } \\
\text { Order } 1 \mathrm{p} \text {-value } \\
\text { Order } 2 \text { p-value }\end{array}$ & $\begin{array}{l}0.182 \\
0.372\end{array}$ & $\begin{array}{l}0.192 \\
0.377\end{array}$ & $\begin{array}{l}0.168 \\
0.407\end{array}$ & $\begin{array}{l}0.181 \\
0.399\end{array}$ & $\begin{array}{l}0.181 \\
0.395\end{array}$ & $\begin{array}{c}0.181 \\
0.342\end{array}$ & $\begin{array}{l}0.184 \\
0.284\end{array}$ \\
\hline
\end{tabular}


Table (13): Financial Inclusion \& Macroprudential Policy

Dependent variable: Borrowers from commercial banks (per 1000 adults).

Estimation Method: Arellano-Bover/Blundell-Bond Dynamic Panel System GMM.

\begin{tabular}{|c|c|c|}
\hline VARIABLES & $\begin{array}{c}\text { (1) } \\
\text { borrowers_banks }\end{array}$ & $\begin{array}{c}(2) \\
\text { borrowers_banks }\end{array}$ \\
\hline $\operatorname{AR}(1)$ & $\begin{array}{l}0.982 * * * \\
(0.0252)\end{array}$ & $\begin{array}{l}0.986 * * * \\
(0.0222)\end{array}$ \\
\hline Unemployment & $\begin{array}{c}2.105 * * * \\
(0.587)\end{array}$ & $\begin{array}{c}2.139 \\
(1.998)\end{array}$ \\
\hline Secondaryenrolment & $\begin{array}{l}-0.231 * \\
(0.118)\end{array}$ & $\begin{array}{c}-0.371 \\
(0.259)\end{array}$ \\
\hline Urbanization & $\begin{array}{l}0.249 * \\
(0.135)\end{array}$ & $\begin{array}{l}0.415^{*} \\
(0.239)\end{array}$ \\
\hline Openness & $\begin{array}{r}-0.00748 \\
(0.0628)\end{array}$ & $\begin{array}{c}0.0612 \\
(0.0847)\end{array}$ \\
\hline RRR (actual) & $\begin{array}{l}-0.693 \\
(0.587)\end{array}$ & \\
\hline Interaction: findevv_rr_act & $\begin{array}{l}8.253 * * \\
(3.457)\end{array}$ & \\
\hline 1t_LTV & & $\begin{array}{l}42.16 * \\
(24.11)\end{array}$ \\
\hline Interaction: findevv_lt_ltv & & $\begin{array}{l}-112.6 \\
(93.57)\end{array}$ \\
\hline Total Effect & $\begin{array}{l}7.560 * * \\
(3.023)\end{array}$ & $-70.47 \quad(71.086)$ \\
\hline $\begin{array}{l}\text { Observations } \\
\text { Number of code }\end{array}$ & $\begin{array}{c}303 \\
46 \\
\end{array}$ & $\begin{array}{c}133 \\
23\end{array}$ \\
\hline $\begin{array}{l}\text { Arellano-Bond Test } \\
\text { Order } 1 \text { p-value } \\
\text { Order } 2 \text { p-value }\end{array}$ & $\begin{array}{c}0.35 \\
0.262\end{array}$ & $\begin{array}{c}0 . .088 \\
0.360\end{array}$ \\
\hline
\end{tabular}

Standard errors in parentheses

$* * * \mathrm{p}<0.01, * * \mathrm{p}<0.05, * \mathrm{p}<0.1$ 
Table (14): Financial Inclusion \& Macroprudential Policy

Dependent variable: Depositors in commercial banks (per 1000 adults)

Estimation Method: Arellano-Bover/Blundell-Bond Dynamic Panel System GMM.

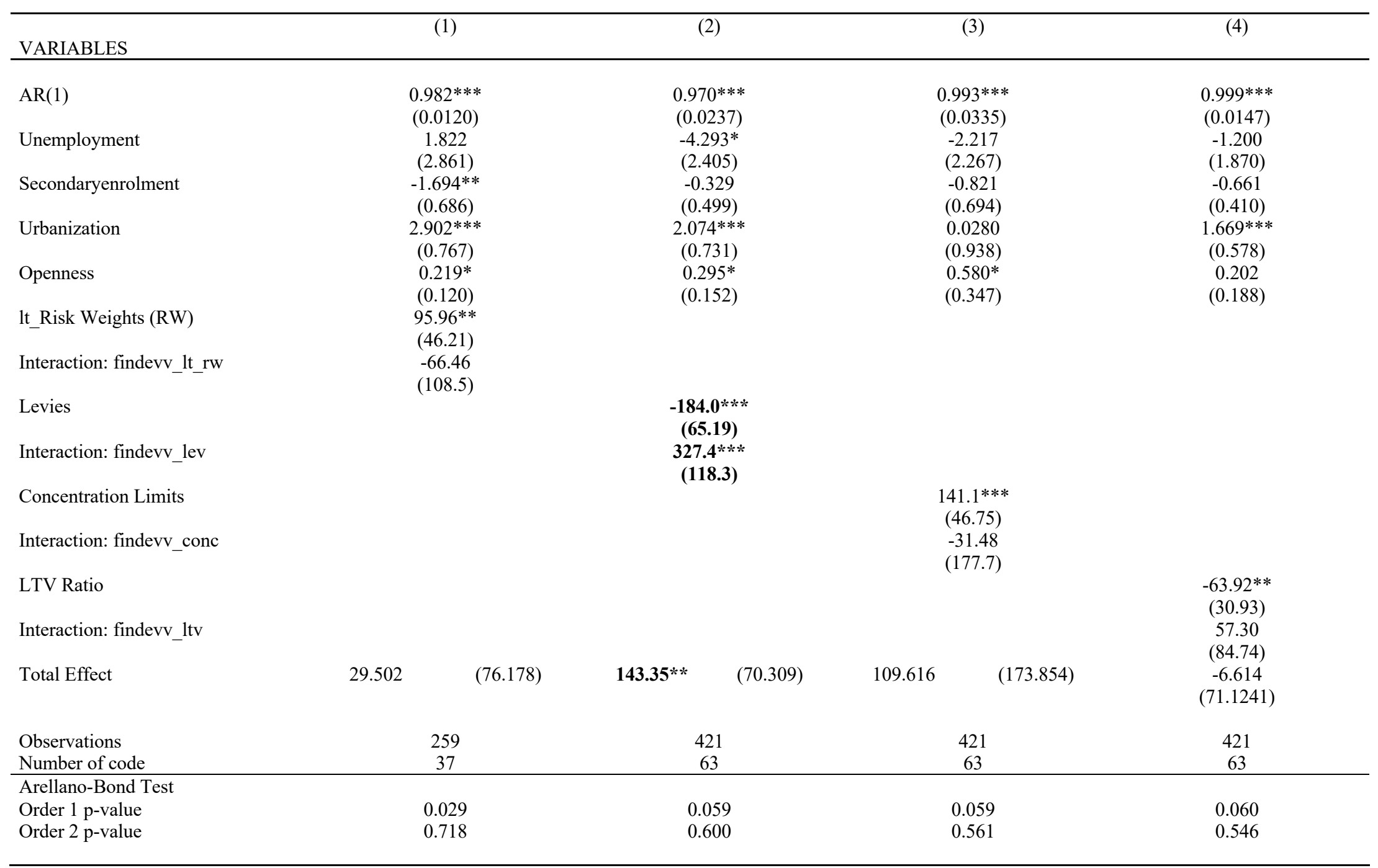




\section{Robustness checks}

For robustness we employed a significant number of additional explanatory variables including alternative measures of education, dependency ratios, fiscal and investment data, value added by industry, investment, household expenditure, GDP per capita, inflation, savings, and interest rates. Most of them, however, were not significant. We also performed cross-sectional regressions (OLS and 2SLS), with the results differing, particularly for the former due to endogeneity, using alternative definitions of financial inclusions.

\section{Conclusions and Policy Implications}

We have attempted to analyze the impact of macroprudential policies on financial inclusion in a panel of 67 countries over the period 2000-2014. Using System-GMM regressions, we find that macroprudential policies have mixed effects on financial inclusion, and the results vary by the level of governance and institutional quality. Overall provisioning appears to have a consistently positive impact on financial inclusion, both in terms of access, and usage of financial services, while debt to income ratios and LTV ratios reduced it. Reserve requirements, particularly if implemented countercyclically, had a positive impact on financial inclusion, a result that supports some of the theoretical research recently conducted. Even more so, reserve requirements have a positive impact on financial inclusion when implemented with better governance and financial development.

Governance, and institutional quality appear to improve the effectiveness of macroprudential policies in a way that does not jeopardize financial inclusion. Financial development helps macroprudential policies improve usage of financial services - both borrowing and depositing - but does not significantly help in increase financial access. This is a plausible argument as it is assumed that higher development could potentially translate into higher financial access, and macroprudential policies would not necessarily affect it. Macroprudential policies, thus appear to increase the usage of financial services as financial development increase, among those already financially included.

As for governance, we find that improved institutional quality increases both financial access, and usage, with limited adverse effects either on usage or access. Our results point to important policy implications. A country's level of institutional quality and financial development plays an important role in the effectiveness of macroprudential policies. Specifically, an improvement of institutional quality, irrespective of a country's level of financial development, increases the effectiveness of macroprudential policies in boosting financial inclusion, a result 
not necessarily achieved without the presence of strong institutions, and increased levels of financial development. These findings are important as they shed light on the importance of institutional quality in improving the effectiveness of macroprudential policies.

Overall the benefits of macroprudential policies on their impact on financial inclusion appears to outweigh their costs. Given the importance of financial inclusion for financial stability, we are inclined to believe that macroprudential policies contribute to financial stability given their impact on financial inclusion. While some unintended - negative - consequences exist, institutional quality in particular appears to help dampen those negative consequences.

Further research will assess the interaction of both macroprudential policies and financial inclusion on financial stability, as well as the impact of the various macroprudential tools on firm access to finance and compare them to household access to finance, to reach even more robust conclusions. Using alternative measures that capture institutional quality (International Country Risk Guide (ICRG) or Business Environment Risk Intelligence (BERI), and macroprudential policies will be a useful extension to test the robustness of the presented results, in addition to using actual values of macroprudential policies to examine the magnitude of their impact on financial inclusion is also important. We believe that this is an unexplored area with potential for further analysis on the role of financial inclusion for macroprudential policies. 


\section{Annex I}

Table (1): List of Advanced Economies included in the Sample ${ }^{72}$

\begin{tabular}{|c|c|c|}
\hline Australia & Hong Kong & Portugal \\
\hline Austria & Ireland & Singapore \\
\hline Belgium & Israel & Slovakia \\
\hline Canada & Italy & Slovenia \\
\hline Cyprus & Japan & South Korea \\
\hline Czech Republic & Luxembourg & Spain \\
\hline Denmark & Malta & Sweden \\
\hline Finland & Netherlands & Switzerland \\
\hline France & New Zealand & United Kingdom \\
\hline Germany & Norway & United States \\
\hline Greece & & \\
\hline
\end{tabular}

Table (2): List of EMs included in the Sample

\begin{tabular}{|c|c|c|c|c|c|}
\hline Albania & Bulgaria & Hungary & Macedonia & Philippines & $\begin{array}{c}\text { Trinidad and } \\
\text { Tobago }\end{array}$ \\
\hline Algeria & Burundi & India & Malaysia & Poland & Tunisia \\
\hline Angola & Chile & Indonesia & Mauritius & Qatar & Turkey \\
\hline Argentina & China & Jamaica & Mexico & Romania & Ukraine \\
\hline Azerbaijan & Colombia & Jordan & Montenegro & $\begin{array}{c}\text { Russian } \\
\text { Federation }\end{array}$ & Uruguay \\
\hline Bahrain & Costa Rica & Kazakhstan & Morocco & Saudi Arabia & $\begin{array}{c}\text { United Arab } \\
\text { Emirates }\end{array}$ \\
\hline Belize & Croatia & Kuwait & Oman & Serbia & Venezuela \\
\hline $\begin{array}{l}\text { Bosnia and } \\
\text { Herzegovina }\end{array}$ & Ecuador & Latvia & Pakistan & South Africa & \\
\hline Botswana & Egypt & Lebanon & Paraguay & Sri Lanka & \\
\hline Brazil & $\begin{array}{c}\text { El } \\
\text { Salvador }\end{array}$ & Lithuania & Peru & Thailand & \\
\hline
\end{tabular}

\footnotetext{
${ }^{72}$ Country Classification is based on the IMF
} 


\section{Table (3): Definition of Variables}

\begin{tabular}{|c|c|c|}
\hline Variable Name & Definition & Source \\
\hline Financial Institutions Access & Bank branches per 100,000 adults and ATMs per 100,000 adults & $\begin{array}{l}\text { IMF Financial Development } \\
\text { Database }\end{array}$ \\
\hline Financial Markets Access & $\begin{array}{l}\text { Percent of market capitalization outside of top } 10 \text { largest companies and Total number of issuers of } \\
\text { debt (domestic and }\end{array}$ & $\begin{array}{l}\text { IMF Financial Development } \\
\text { Database }\end{array}$ \\
\hline Account (\% age 15+) [ts] & Percent of respondents who report having an account (by themselves or together with someone else). & World Bank Findex Database \\
\hline Account at a financial institution (\% age $15+$ ) [ts] & $\begin{array}{l}\text { Percent of respondents with an account (self or together with someone else) at a bank, credit union, } \\
\text { another financial institution (e.g., cooperative, microfinance institution), or the post office (if }\end{array}$ & World Bank Findex Database \\
\hline $\begin{array}{l}\text { Automated teller machines (ATMs) (per 100,000 } \\
\text { adults) }\end{array}$ & $\begin{array}{l}\text { Automated teller machines are computerized telecommunications devices that provide clients of a } \\
\text { financial institution with access to financial transactions in a public place. }\end{array}$ & $\begin{array}{l}\text { IMF Financial Development } \\
\text { Database }\end{array}$ \\
\hline Bank accounts per 1,000 adults & & IMF Financial Access Survey \\
\hline Commercial bank branches (per 100,000 adults) & $\begin{array}{c}\text { Commercial bank branches are retail locations of resident commercial banks and other resident banks } \\
\text { that function as commercial banks that provide financial services to customers and are physically } \\
\text { separated from the main office but not organized as legally separated subsidiaries. }\end{array}$ & $\begin{array}{l}\text { IMF Financial Development } \\
\text { Database }\end{array}$ \\
\hline Borrowers at commercial banks per 1,000 adults & $\begin{array}{l}\text { Number of resident customers that are nonfinancial corporations (public and private) and households } \\
\text { who obtained loans from commercial banks and other banks functioning as commercial banks per } \\
\qquad 1000 \text { adults. }\end{array}$ & IMF Financial Access Survey \\
\hline $\begin{array}{l}\text { Depositors with commercial banks per } 1,000 \\
\text { adults }\end{array}$ & $\begin{array}{l}\text { Reported number of deposit account holders at commercial banks and other resident banks } \\
\text { functioning as commercial banks that are resident nonfinancial corporations (public and private) and } \\
\text { households. }\end{array}$ & IMF Financial Access Survey \\
\hline Financial Institutions Depth & $\begin{array}{l}\text { Private-sector credit to GDP ; Pension fund assets to GDP ; Mutual fund assets to GDP ; Insurance } \\
\text { premiums, life and non-life to GDP }\end{array}$ & $\begin{array}{l}\text { IMF Financial Development } \\
\text { Database }\end{array}$ \\
\hline Financial Markets Depth & $\begin{array}{c}\text { Stock market capitalization to GDP; Stocks traded to GDP; International debt securities of government } \\
\text { to GDP; Total debt securities of financial corporations to GDP; Total debt securities of nonfinancial } \\
\text { corporations to GDP }\end{array}$ & $\begin{array}{l}\text { IMF Financial Development } \\
\text { Database }\end{array}$ \\
\hline
\end{tabular}

\begin{tabular}{|l|l|l|}
\hline Unemplyment & Unemployment, total (\% of total labor force) (national estimate) & WDI \\
\hline Secondaryenrol & Progression to secondary school (\%) & WDI \\
\hline Urbanization & Urban population (\% of total) & WDI \\
\hline Terms of Trade & Net barter terms of trade index (2000 = 100) & WDI \\
\hline Savings & Gross domestic savings (\% of GDP) & WDI \\
\hline Financial Development & $\begin{array}{l}\text { A measure capturing financial depth (size and liquidity of markets), and } \\
\text { financial efficiency in financial markets and financial institutions (ability } \\
\text { of institutions to provide financial services at low cost and with } \\
\text { sustainable revenues, and the level of activity of capital markets). }\end{array}$ & IMF FD Database \\
\hline
\end{tabular}


Table (4): Macroprudential Tools

\begin{tabular}{|c|c|c|}
\hline Tool & Definition & Source \\
\hline Loan-to-Value Ratio & $\begin{array}{l}\text { Constrains highly levered mortgage downpayments by enforcing or } \\
\text { encouraging a limit or by determining regulatory risk weights. }\end{array}$ & Cerutti (2015) \\
\hline Debt-to-Income Ratio & $\begin{array}{l}\text { Constrains household indebtedness by enforcing or encouraging a } \\
\text { limit. }\end{array}$ & Cerutti (2015) \\
\hline $\begin{array}{l}\text { Time-Varying/Dynamic } \\
\text { Loan-Loss Provisioning }\end{array}$ & Requires banks to hold more loan-loss provisions during upturns. & Cerutti (2015) \\
\hline $\begin{array}{c}\text { General Countercyclical } \\
\text { Capital } \\
\text { Buffer/Requirement }\end{array}$ & Requires banks to hold more capital during upturns. & Cerutti (2015) \\
\hline Leverage Ratio & Limits banks from exceeding a fixed minimum leverage ratio. & Cerutti (2015) \\
\hline $\begin{array}{l}\text { Capital Surcharges on } \\
\text { SIFIs }\end{array}$ & $\begin{array}{l}\text { Requires Systemically Important Financial Institutions to hold a higher } \\
\text { capital level than other financial institutions. }\end{array}$ & Cerutti (2015) \\
\hline $\begin{array}{l}\text { Limits on Interbank } \\
\text { Exposures }\end{array}$ & $\begin{array}{l}\text { Limits the fraction of liabilities held by the banking sector or by } \\
\text { individual banks. }\end{array}$ & Cerutti (2015) \\
\hline Concentration Limits & Limits the fraction of assets held by a limited number of borrowers. & Cerutti (2015) \\
\hline $\begin{array}{l}\text { Limits on Foreign } \\
\text { Currency Loans }\end{array}$ & Reduces vulnerability to foreign-currency risks. & Cerutti (2015) \\
\hline $\begin{array}{l}\text { Reserve Requirement } \\
\text { Ratios }\end{array}$ & $\begin{array}{l}\text { Limits credit growth; can also be targeted to limit foreign-currency } \\
\text { credit growth. }\end{array}$ & Cerutti (2015) \\
\hline $\begin{array}{l}\text { Limits on Domestic } \\
\text { Currency Loans }\end{array}$ & Limits credit growth directly. & Cerutti (2015) \\
\hline $\begin{array}{l}\text { Levy/Tax on Financial } \\
\text { Institutions }\end{array}$ & Taxes revenues of financial institutions. & Cerutti (2015) \\
\hline Loan-to-Value Ratio Caps & $\begin{array}{l}\text { Restricts to LTV used as a strictly enforced cap on new loans, as } \\
\text { opposed to a supervisory guideline or merely a determinant of risk } \\
\text { weights. }\end{array}$ & Cerutti (2015) \\
\hline $\begin{array}{l}\text { FX and/or Countercyclical } \\
\text { Reserve Requirements }\end{array}$ & $\begin{array}{l}\text { Restricts to RR which i) imposes a wedge of on foreign currency ; or } \\
\text { ii) is adjusted countercyclically }\end{array}$ & Cerutti (2015) \\
\hline $\begin{array}{l}\text { Overall Macroprudential } \\
\text { Index }\end{array}$ & $\begin{array}{l}\text { An index capturing the measures included in Cerutti's index if they } \\
\text { were implemented; LTV ratios, Dti ratios, concentration limits, } \\
\text { counter-cyclical capital buffer, taxes on financial institutions, capital } \\
\text { surgecharests on SIFIs. }\end{array}$ & Cerutti (2015) \\
\hline $\begin{array}{l}\text { Borrower-Targeted } \\
\text { Instruments }\end{array}$ & $\begin{array}{l}\text { An index reflecting macroprudential policies that target borrowers; } \\
\text { Debt to Income Ratio and Loan to Value Ratio }\end{array}$ & Cerutti (2015) \\
\hline $\begin{array}{l}\text { Financial Institution- } \\
\text { Targted Instruments }\end{array}$ & $\begin{array}{l}\text { An index capturing macroprudential policies that target financial } \\
\text { incstitutions; dynamic provisionings, countercyclical capital buffers, } \\
\text { and RRR's, levies, surcharges on systemically important financial } \\
\text { institutions, limits on interbank exposurs, concentation limits, foreign } \\
\text { currency limites, and limits on domestic currency loans }\end{array}$ & Cerutti (2015) \\
\hline
\end{tabular}




\begin{tabular}{|c|c|c|}
\hline LT_Liq & Losening/Tightening Liquidity Requirements & $\begin{array}{l}\text { Shim et. Al. } \\
(2016)\end{array}$ \\
\hline rr act & Actual Required Reserve Ratio Figures & $\begin{array}{l}\text { Authors' } \\
\text { Collections }\end{array}$ \\
\hline Credit Growth Limits & $\begin{array}{l}\text { Imposition of a quantitative ceiling on the rate of credit growth over a } \\
\text { specific period of time }\end{array}$ & $\begin{array}{l}\text { Shim et. Al. } \\
(2016)\end{array}$ \\
\hline Risk Weights & $\begin{array}{l}\text { Higher risk weights makes it more expensive for banks to extend } \\
\text { particular types of loans (e.g. housing loans) }\end{array}$ & $\begin{array}{l}\text { Shim et. Al. } \\
(2016)\end{array}$ \\
\hline LT LTV & Losening/Tightening LTV & $\begin{array}{l}\text { Shim et. Al. } \\
(2016)\end{array}$ \\
\hline LT_Provisioning & Losening/Tightening LTV & $\begin{array}{l}\text { Shim et. Al. } \\
(2016)\end{array}$ \\
\hline $\begin{array}{l}\text { LT_Risk credit growth } \\
\text { limits }\end{array}$ & Losening/Tightening of monthly limits on credit growth & $\begin{array}{l}\text { Shim et. Al. } \\
(2016)\end{array}$ \\
\hline LT_Taxes & Losening/Tightening Taxes & $\begin{array}{l}\text { Shim et. Al. } \\
(2016)\end{array}$ \\
\hline LT_RR2 & Losening/Tightening of required reserve based on our own collections & $\begin{array}{l}\text { Authors' } \\
\text { Collections } \\
\end{array}$ \\
\hline LT_LTV & Losening/Tightening LTV & $\begin{array}{l}\text { Shim et. Al. } \\
(2016)\end{array}$ \\
\hline LT_LTV & Losening/Tightening LTV & $\begin{array}{l}\text { Shim et. Al. } \\
(2016)\end{array}$ \\
\hline rr magnitude & $\begin{array}{l}\text { Reflects changes in required reserve ratios to show the extent of the } \\
\text { change and its impact }\end{array}$ & $\begin{array}{l}\text { Shim et. Al. } \\
(2016)\end{array}$ \\
\hline LT_Expo & Exposure Limit & $\begin{array}{l}\text { Shim et. Al. } \\
(2016)\end{array}$ \\
\hline
\end{tabular}


Table (5): Summary Statistics

\begin{tabular}{|c|c|c|c|c|c|}
\hline Variable & Obs & Mean & Std. Dev. & Min & Max \\
\hline Urbanization & 1,921 & 62.05214 & 22.19357 & 8.352 & 100 \\
\hline Unemployment & 1,594 & 8.923777 & 6.646062 & 0.1 & 57 \\
\hline Openness & 1,909 & 92.24231 & 59.22104 & 19.1008 & 442.62 \\
\hline Secondary Enrolment & 1,458 & 87.66564 & 23.79722 & 13.77945 & 166.8085 \\
\hline Financial Institution Depth & 1,665 & 0.3310777 & 0.2832979 & 0.0045977 & 1 \\
\hline Financial Institution Access & 1,665 & 0.3948678 & 0.2894931 & 0 & 1 \\
\hline Financial Institution Efficiency & 1,665 & 0.5929839 & 0.1414308 & 0.0906417 & 0.8792366 \\
\hline Financial Markets Depth & 1,665 & 0.3106568 & 0.3026897 & 0 & 0.9994659 \\
\hline Financial Markets Access & 1,665 & 0.3089447 & 0.3185427 & 0 & 1 \\
\hline Financial Markets Efficiency & 1,665 & 0.3292632 & 0.3658282 & 0 & 1 \\
\hline ATMS & 1,213 & 50.81656 & 47.24685 & 0 & 290.14 \\
\hline Bank Accounts & 551 & 710.6393 & 570.0839 & 0.41 & 3371.49 \\
\hline Bank Branches & 1,275 & 20.78522 & 19.96302 & 0.45 & 257.7 \\
\hline Provisioning & 1,266 & 73.62769 & 46.63855 & 0 & 604.07 \\
\hline LTV Caps & 1,456 & 0.1641484 & 0.3705374 & 0 & 1 \\
\hline Debt to Income Ratio & 1,456 & 0.125 & 0.3308325 & 0 & 1 \\
\hline Dynamic Provisioning & 1,456 & 0.0776099 & 0.2676486 & 0 & 1 \\
\hline Countercyclical Capital Requirements & 1,456 & 0.0178571 & 0.1324776 & 0 & 1 \\
\hline Levies & 1,456 & 0.1229396 & 0.3284806 & 0 & 1 \\
\hline $\begin{array}{l}\text { Systemically Important Financial Institutions } \\
\text { Surcharges }\end{array}$ & 1,456 & 0.0096154 & 0.097619 & 0 & 1 \\
\hline Interbank Exposure Limits & 1,456 & 0.2527473 & 0.4347366 & 0 & 1 \\
\hline Concentration Limits & 1,456 & 0.6057692 & 0.4888527 & 0 & 1 \\
\hline LTV ratio caps & 1,456 & 0.2156593 & 0.4114203 & 0 & 1 \\
\hline Taxes & 1,456 & 0.1195055 & 0.3244938 & 0 & 1 \\
\hline Limits on Domestic Currency Lending & 1,456 & 0.0947802 & 0.2930118 & 0 & 1 \\
\hline Countercyclical Reserve Requirements & 1,456 & 0.1565934 & 0.3635419 & 0 & 1 \\
\hline Reserve Requirements & 1,939 & 0.8509541 & 0.3562256 & 0 & 1 \\
\hline Foreign Currency Limits & 1,459 & 0.107608 & 0.3099909 & 0 & 1 \\
\hline Overall Macroprudential Index & 1,456 & 1.854396 & 1.580624 & 0 & 8 \\
\hline Borrower Targeted Instruments & 1,456 & 0.3166209 & 0.6533223 & 0 & 4 \\
\hline Financial Targeted Instruments & 1,456 & 1.565247 & 1.322759 & 0 & 6 \\
\hline Required Reserve Ratio (Actual data collection) & 1,669 & 7.332819 & 7.441161 & 0 & 80 \\
\hline Losening/Tighening_rr & 1,142 & 0.0140105 & 0.9133233 & -6 & 10 \\
\hline Losening/Tighening_liq & 741 & 0.0080972 & 0.2985357 & -3 & 6 \\
\hline Losening/Tighening_cr & 741 & 0.0013495 & 0.0821884 & -1 & 1 \\
\hline Losening/Tighening_ltv & 741 & 0.048583 & 0.3894747 & -1 & 5 \\
\hline Losening/Tighening_dti & 741 & 0.0350877 & 0.241302 & -1 & 2 \\
\hline Losening/Tighening_rw & 741 & 0.0215924 & 0.2314891 & -1 & 1 \\
\hline Losening/Tighening_prov & 741 & 0.0296896 & 0.236377 & -1 & 3 \\
\hline Losening/Tighening_expo & 741 & 0.0013495 & 0.1423673 & -2 & 1 \\
\hline Losening/Tighening tax & 741 & 0.0107962 & 0.3818759 & -3 & 2 \\
\hline Losening/Tighening_rr2 & 1,674 & 0.0298686 & 0.5652344 & -2 & 2 \\
\hline
\end{tabular}




\begin{tabular}{|l|r|r|r|r|r|} 
& 1,570 & 0.0578917 & 2.742392 & -56 & 20 \\
\hline Grmag & 1,824 & 0.1411042 & 1.047821 & -1.722249 & 2.469991 \\
\hline Governance: Corruption & 1,815 & 0.2628747 & 0.9552625 & -2.058268 & 2.436975 \\
\hline Governance: Political Stability & 1,812 & 0.0247487 & 0.9542523 & -2.810035 & 1.760102 \\
\hline Governance: Regulatory Quality & 1,814 & 0.2867892 & 0.9054986 & -2.027446 & 2.260543 \\
\hline Governance: Rule of Law & 1,824 & 0.1610754 & 0.990082 & -2.178493 & 2.100273 \\
\hline Governance: Voice and Accountability & 1,824 & 0.1135349 & 0.9391642 & -1.907197 & 1.800992 \\
\hline $\begin{array}{l}\text { Borowers within Commercial Banks (per 1000 } \\
\text { adults) }\end{array}$ & 669 & 231.6199 & 219.2247 & 0.0182538 & 1232.996 \\
\hline $\begin{array}{l}\text { Depositors within Commercial Banks (per 1000 } \\
\text { adults) }\end{array}$ & 898 & 1365.367 & 1253.939 & 2.162313 & 7987.93 \\
\hline
\end{tabular}

\section{References:}

Ahamed, M.M., and S. K. Mallick. (2017). Is Financial Inclusion Good for Bank Stability? International Evidence. Journal of Economic Behavior and Organization.

Allen, F., Demirguc-Kunt, A., Klapper, L., and M.S. Martinez-Peria. (2016). The Foundations of Financial Inclusion. Journal of Financial Intermediation, 27, pp. 1-30.

Ampudia, M. and M. Ehrmann. (2017). Financial Inclusion: What's it worth? ECB Working Paper No. 1990.

Arellano, M. and S. Bond. (1991). Some Tests of Specification for Panel Data: Monte Carlo Evidence and an Application to Employment Equations, Review of Economic Studies, 58, pp. 277-297.

Aterido, R., and M. Hallward-Driemeier. (2010). The Impact of the Investment Climate on Employment Growth: Does Sub-Saharan Africa Mirror Other Low-Income Regions? World Bank.

Ayyagari, M., Demirguc-Kunt, A., and V. Maksimovic. (2008). How Important Are Financing Constraints? The Role of Finance in the Business Environment. World Bank Economic Review, 22(3), pp. 483-516.

Ayyagrari, M., Beck, T., and M.S.M. Peria. (2017). Credit growth and macro prudential policies: Preliminary evidence on the firm level.

Bacchetta, P., and S. Gerlach. (1997). Consumption and Credit Constraints: International Evidence. Journal of Monetary Economics, 40, pp. 207-238.

Bank of England (2009). The role of macroprudential policy, Bank of England Discussion Paper, November.

Baskaya, Y.S., Kenc, T., Shim, I., and P. Turner. (2016). Financial development and the effectiveness of macroprudential measures. In Bank for International Settlements Paper No. 86: Macroprudential Policy.

Beck, T. (2016). Financial Inclusion - Measuring Progress and Progress In Measuring. 
Beck, T., Demirguc-Kunt A., Laeven, L., and V. Maksimovic. (2006). The Determinants of Financing Obstacles. Journal of International Money and Finance, 25 (6), pp. 932-52.

Beck, T., Demirguc-Kunt, A., and R. Levine. (2007). Finance, Inequality, and the Poor. Journal of Economic Growth, 12 (1), pp. 7-49.

Beck, T., Demirguc-Kunt, A., and V. Maksimovic. (2005). Financial and Legal Constraints to Firm Growth: Does Firm Size Matter? Journal of Finance, 60 (1), pp. 137-77.

Beck, T., Demirguc-Kunt, A., Laeven, L., and R. Levine. (2008b). Finance, firm size, and growth. Journal of Money, Credit, and Banking, 40 (7), pp. 1379-1405.

Berben, J.P., Beirut, B., van den End, J.W., and J. Kakes. (2010). Macro-effects of higher capital and liquidity requirements for banks. Empirical evidence for the Netherlands. DNB Occasional Studies, $8(3)$.

Brownbridge, M., Bwire, T., Rubatsimbira, D.K., and G.A., Tinyinondi. (2017). The Impact of Financial Inclusion on the Interest Rate Channel of the Monetary Policy Transmission Mechanism.

Butler, A.W., and J. Cornaggia. (2011). Does Access to Finance Improve Productivity? Evidence from a Natural Experiment. Journal of Financial Economics, 99(1), pp. 184-203.

Caselli, F., G., Esquivel and F. Lefort. (1996). Reopening the Convergence Debate: A New Look at CrossCountry Growth Empirics, Journal of Economic Growth, 1(3), pp. 363-89.

Cerutti, E., Claessens, S., and L. Laeven. (2015). The Use and Effectiveness of Macroprudential Policies: New Evidence. IMF Working Paper 15/61, March.

Cihak, M., Mare, D.S., and M. Melecky (2016). The Nexus of Financial Inclusion and Financial Stability: A Study of Trade-Offs and Synergies.

Cull, R., Demirguc-Kunt, A., and T. Lyman. (2012). Financial Inclusion and Stability: What Does Research Show? CGAP Policy Brief.

Dabla-Norris, E., Townsend, R., Ji, Y., and D. F. Unsal. (2015). Identifying Constraints to Financial Inclusion and Their Impact on GDP and Inequality: A Structural Framework for Policy. IMF Working Paper 15/22.

Demirguc-Kunt, A. (2017). What do we Know about the Link between Financial Inclusion and Inclusive Growth.

Demirguc-Kunt. A. and V. Maksimovic. (1998). Law, Finance, and Firm Growth. Journal of Finance, 53 (6), pp. 2107-2137.

Demirguc-Kunt. A. and V. Maksimovic. (2006). Business Environment and the Incorporation Decision. Journal of Banking and Finance, 30(11), pp. 2967-2933. 
Dinh., H.T., Mavridis., D.A., and H.B. Nguyen. (2010). The Binding Constraint on the Growth of Firms in Developing Countries. World Bank Policy Research Paper 5485.

Dupas, P., and J. Robinson. (2013). Savings Constraints and Microenterprise Development: Evidence from a Field Experiment in Kenya, American Economic Journal: Applied Economics, 5, pp. 163-92.

Evans, O. (2015). The Effects of Economic and Financial Development on Financial Inclusion in Africa. Review of Economic and Development Studies, 1(1), pp. 17-25.

Fowowe, B. (2017). Access to Finance and Firm Performance: Evidence from African Countries. Review of Development Finance, 7(1), pp. 6-17.

Fungáčová, Z. and L. Weill. (2014). Understanding Financial Inclusion in China. Bank of Finland Institute for Economies in Transition Discussion Paper number 10.

Galati, G., and R. Moessner. (2011). Macroprudential Policy- A Literature Review. Bank for International Settlement Working Paper No. 337.

Gimet, C., and T. Lagoarde-Segot. (2012). Financial Sector Development and Access to Finance: Does Size Say it All? Emerging Markets Review, 13, pp. 316-337.

Gould, D.M., and M. Melecky. (2017). Risk and Returns: Managing Financial Trade-Offs for Inclusive Growth in Europe and Central Asia.

Granville, B. and S. Mallick. (2009). Monetary and financial stability in the euro area: Pro-cyclicality versus trade-off. Journal of International Financial Markets, Institutions and Money, 19(4), pp. 662-674.

Grima, S., Gong, Y., and H. Gorg. (2008). Foreign Direct Investment, Access to Finance, and Innovation Activity in Chinese Enterprises. World Bank Economic Review, 22(2), pp 367-382.

Han, R., and M. Melecky. (2013). Financial Inclusion for Financial Stability: Access to Bank Deposits and the Growth of Deposits in the Global Financial Crisis. World Bank Policy Research Working Paper 6577.

Holtz-Eakin, D., W. Newey and H. Rosen. (1988). Estimating Vector Autoregressions with Panel Data, Econometrica, 56, pp. 1371-1395.

Honohan, P. (2008). Cross-country variation in household access to financial services. Journal of Banking \& Finance, 32 (2008), pp. 2493-2500.

Honohan, P., and M. King. (2009). Cause and Effect of Financial Access: Cross-Country Evidence from the Finscope Surveys.

IMF. (2016). Capital Flows- Review of Experience with the Institutional View.

IMF. (2017). IMF Fiscal Monitor: Tracking Inequality. October. 
IMF. (2018). Financial Inclusion and Economic Inequality: A cross-country Analysis. IMF Working Paper (Forthcoming), findings presented at the EEFS 2018 Annual Conference.

Jappelli, T., and M. Pagano (1989). Aggregate Consumption and Capital Market Imperfections: An International Comparison. American Economic Review, 79, pp. 1088-1105.

Karlan, D., Ratan, A.L., and J. Zinman. (2014). Savings By and For the Poor: A Research Review and Agenda. Center for Global Development Working Paper No. 346.

Lenka, K. S., and K.A. Bairwa. (2016). Does financial inclusion affect monetary policy in SAARC countries? Cogent Economics \& Finance, 4: 1127011.

Ludvigson, S., (1999). Consumption and Credit: A Model of Time-Varying Liquidity Constraints. The Review of Economics and Statistics, 81, pp. 434-447.

Mehrotra, A., and J. Yetman. (2015). Financial inclusion- issues for central banks.

Morgan, P.J., and V. Pontines. (2014). Financial Stability and Financial Inclusion. Asian Development Bank Institute Working Paper Series No. 488.

Neaime, S. and I. Gaysset. (2017). Financial inclusion and stability in MENA: Evidence from poverty and inequality. Finance Research Letters.

Oyelami, L.O., Saibu, O.M., and B.S. Adekunle. (2017). Determinants of Financial Inclusion in Sub-Sahara African Countries. Covenant Journal of Business \& Social Sciences, 8(2), pp. 104-116.

Pal, R., and R. Pal. (2012). Income Related Inequality in Financial Inclusion and Role of Banks: Evidence on Financial Exclusion in India. Indira Gandhi Institute of Development Research Working Paper No. WP-2012-013.

Park, C.-Y., and R. V. Mercado. (2015). Financial Inclusion, Poverty, Income Inequality in Developing Asia. Asian Development Bank Economics Working Paper 426.

Pearlman, J. (2015). A stylized model of European Monetary Union for analyzing coordination games for monetary and macroprudential policy. MACROFINBODS Theoretical Paper D9.1.

Pearlman, J., and A. Mirza. (2017). A model of contagion within a fiscal policy framework. MACROFINBODS Theoretical Paper D9.3.

Prasad, E. (2010). Financial Sector Regulation and Reforms in Emerging Markets: An Overview: NBER Working Paper 16428.

Rojas-Suarez, L., and V. Gonzales. (2010). Access to Financial Services in Emerging Powers: Facts, Obstacles and Policy Implications. OECD Development Center.

Sarma, M., and J. Pais. (2008). Financial Inclusion and Development: A Cross-Country Analysis. 
Shim, I., Bogdanova, B., Shek, J. and A. Subelyte. (2013). Database for Policy Actions on Housing Markets.

Svirydzenka, K. (2016). Introducing a New Broad-based Index of Financial Development. IMF Working Paper 16/5.

Tissot, B., and B. Gadanecz. (2017). Measures of financial inclusion - a central bank perspective. Paper Prepared for a Meeting at the Bank of Morocco - CEMLA - IFC Satellite Seminar at the ISI World Statistics Congress on "Financial Inclusion".

Tuesta, D., Sorensen, G., Haring, A., and N. Camara. (2015). Financial inclusion and its determinants: the case of Argentina. BBVA Working Paper No. 15/03.

Zahongo, P. (2017). Financial Development and Poverty in Developing Countries: Evidence from SubSaharan Africa. International Journal of Economics and Finance, 9(1), pp. 211-220. 